\title{
تقانة الاظهار في الرسم العراقي المعاصر
}

\author{
م.م. أحمد جبارة عبد المسعن

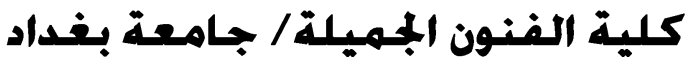 \\ ملنم البهم: \\ تناول البحث مفهوم التقاتة في الفنون الحديثة وكيفية توظيفها في العمل التشكيلي ودورها في تطور الفنون وتنوع الاكتثـافات \\ التي اظلت بظلالها على توسع العمل الفني واعطاؤها صبغة جمالية جديدة معاصرة ، ومدى تأثيراتها في الرسم العراقي المعاصر عند أجيالهه \\ المتعاقبة بدءاً بجيل الرواد وصولاً الى جيل الثباب في الثمانينـات ونهايـة التسعينات حتى الالفين، وعلى مدى نصف قدئ قرن من تأريخ الحركة \\ التثكيلية في العراق. وقد تناول الإطار النظري للبحث في مبحثه الأول الجذر التاريخي للتقنية والاظهار، تناول الجذر التاريخي للتقتية وصولا

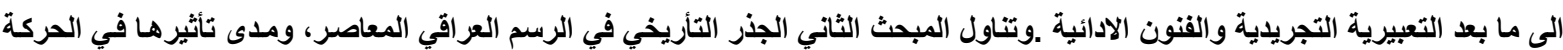

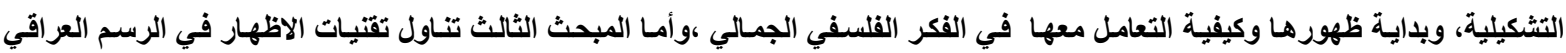 \\ المعاصر. والكثف عن تقنيات الاظهار ومتحولها المعرفي واشكالياتها المتحركة والمتطورة في الثكل والموضوع والمضمون وفقاً لمتغيرات \\ التكنولوجي الحاصل والتغير في البنى الادائية والفكرية والفلسفية والمتغير البيئي ، ونمى ذلك الحراك المعرفي وصولاً إلى مؤشرات الإطار \\ النظري، واجراءات البحث التي اعتمدت منهج التحليل الوصفي لتحليل العينة البالغ عددها(ه)نمـاذج مصورة، وقد خلص البحثى إلى النتائج \\ التي تجيب عن التساؤلات التالية التي طرحها البحث: \\ ا-ما المفاهيم الفكرية والجمالية للتقتيات بوصفها مرجعيات مؤسسة للفن المعاصر في العراق ؟ \\ r-ما المعالجات البنائية والتقتية وكيفية توظيف الخامات على السطح البصري ؟ \\ r-ما اهم المرجعيات التي تأثر بها الرسم العراقي واعتمدها الفنان في توظيف السطح البصري وفي تحديد المفاهيم المادية له ؟
}

\section{Abstract}

Discussion dealt with the concept of technology in modern art how to employ them in the work of plastic and its role in the development of art and the diversity of discoveries that Azlt shadow on the expansion of the artwork and given a dye new aesthetic contemporary, and the extent of their impact in the drawing contemporary Iraqi when generations of successive starting generation of pioneers and down to the younger generation in the eighties and the end nineties until two thousand, and over half a century of the history of art movement in Iraq.

Has dealt with the theoretical framework to discuss Mbgesh first root historical and technical PRESENTATION, addressing the root historical technique down to the post- abstract expressionism and the performing arts . Addressed the second part, the root historical in drawing contemporary Iraqi , and the extent of their impact in the fine movement, and it first appeared, and how to deal with it in philosophical thought aesthetic , and the third topic dealt with in drawing techniques PRESENTATION contemporary Iraqi. And detection techniques Manifesting Tolha cognitive and tribulations animation and sophisticated in form and substance and content according to the variables of technological advances and changes in the structures of the performing and intellectual, philosophical and environmental variable, and grew the mobility of knowledge and access to the indicators of the theoretical framework, and research procedures adopted curriculum descriptive analysis to analyze the sample of $(\bullet)$ pictorial models, has concluded research results that answer the following questions raised by the research

1-What are the concepts of intellectual and aesthetic techniques as references Foundation for Contemporary Art in Iraq?

Y-What are the structural and technical wizards and how to employ visual materials on the surface?

$r$-What are the most important references, which was affected by the drawing of Iraq and adopted by the artist in the recruitment of the optical surface in the determination of the physical concepts to him? 


\section{الففصل الاول}

أولاً: مشكلة البحث:

تماثشيا مـع روح العصـر الثوريـة العلميـة ومو اكبـة معطيـات الحضـارة الحداثيـة الجديدة و التـي يمكن اعتبار ها شكل من اشكال ( صر اع وتطورتكنولوجي ) التي اخذت مساحات و اسعة من البناء الحضـاري الفكري ، وكان من تداعيات هذا الصر اع و التطور ظهور سبل واسـاليب أدائية وشكلية مؤسسـة بمرجعيات موضو عية وحيويـة منـذ بدايـة الانطباعيـة والفنـون الادائيسةالتي اصبحت الرحم الذي ولدت منـه مـدارس الرسـم الحديث و اتجاهاته الفنية بجميع متغير اته المختلفة، وظهور انواع جديدة من التقنيات الاظهاريـة الاسلوبية التي تتناسب و المتغير ات التي شهدها ثورة التقنية في الرسم في اوربا، كما ان ظهور كثرة الحركات و المدارس الفنية في الرسم الحديث جعلته ميدانا للتجريب و المنافسة، وشحنت الفنان في العـالم عامـة وفي العر اق خاصـة على رؤيـة وتجارب جديدة ساعدته على تحول في الاداءات الجمالية وكيفية كثف واختيار وسائل جديدة للاظهار البصري اغنت الموضوع و العمل الفني بمتغيرات جديدة في المفهوم و التنكيل، ممـا تسبب في انتاج وتتوع اعمـال فنيـة فيها تلقائية عالية وحرية وخيال أدت الى إضفاء روحية الغر ائبية على تلك الاعمال التي تطفح بالحرية و التخيل، لتحقيق خطاب عقلي وجداني يتناسب مع صياغة وصناعة وابتكار وتطور إيديولوجي وتكنولوجي و الذي تجو هر

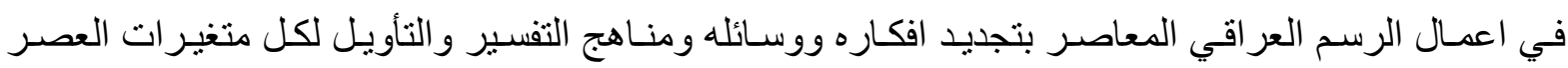

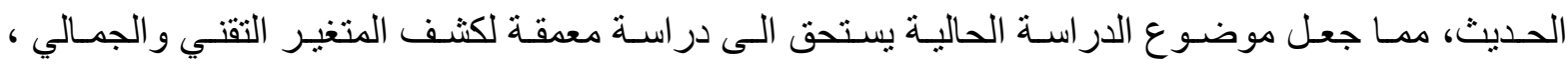
و اساليب الاظهار للسطح البصري في الرسم العر اقي المعاصر ويتم الحديث و التساؤل في هذه الدراسة عن : ما المفاهيم الفكرية والجمالية للتقنيات بوصفها مرجعيات مؤسسة للفن المعاصر في العر اق؟ ما المعالجات البنائية والتقنية وكيفية توظيف الخامات على السطح البصري؟ ما اهم المرجعيات التى تاثربها الرسم العر اقي واعتمدها الفنان في توظيف السطح البصري وفي تحديد المفاهيم الماديه له؟

\section{ثنانياً: اهمية البحث والحاجة إليه:}

تكمـن اهميـة البحـث في الرسـم العر اقي المعاصـر في تسـليط الضـوء على تعيبين مسـار ات التجربـة الاسلوبية والخطاب الفني من طريق التقنيات والمرجعيات الفكريـة والحضـارية، و على اهم المتغيرات التقنية وتوظيف الخامـات وتأثير هـا في المنجز العر اقي، و الكثَف عن مفهوم الوسـائط المتعددة للتقنيات في الرسم العر اقي، فضـلاً عن إضـافة معرفيـة وعلميـة تحليلية للمكتبـة العلميـة والمؤسسـات الفيـة الاكاديميـة التي تعنـي

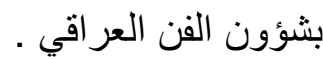

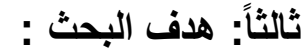

يهدف البحث الحالي إلى: الكثف عن تقانة الاظهار في الرسم العر اقي المعاصر . رابعاً: حدود البحث :

ـالحدود الموضوعية : تقانة الاظهار في الرسم العر اقي المعاصر . 


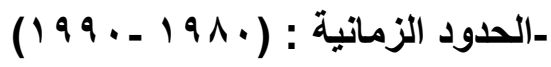
ـالحدود المكانية : النتاجات القنية في العراق . خامساً: تحديد المصطلحات : التقانة: "تعني بالمفهوم القديم مجمو عة من المعطيات التجريبية جمعت وركبت لتحقيق مجموعة من الغايات ، فهي في جوهر ها تشير الى مجمو عة اساليب لمهنة او فن ما، تحولت الى قوانين مضبوطة ومدونة والتي تسمح

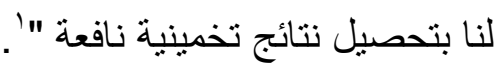

المعاصرة: "تعني التاريخ العصري او الحالي او الحاضر" ‘ُ(المعاصر)" مفهوم نسبي، لمسايرة العصر، في جل

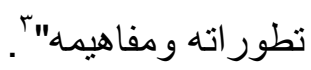
التعريف الاجرائي: التقنية نتاج مهاري و فكري لسلسلة من التجريب وتر اكم الخبرات بستخدمها الفنان من طريق تنوع الاداء، وتوظيفها لتحقيق التحول وتأسيس ومعالجة لعلاقات بنائية وتكوينية جمالية مغايرة في السطح البصري.

\section{النفمل الثخاني الإطار النطري} ـ المبحث الأول- الجذر التاريخي للتقانة والاظهار.

ارتبطت التقانة ارتباطا وثثقاً بالإنسـان و الفنون منذ بدايـة الانسـان وارتباطـه الوثيق و المباثـر بالطبيعـة

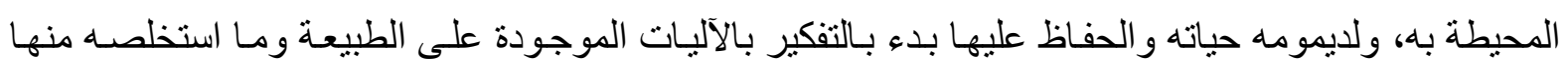
وقام بتغيير ات ادخله عليها و الادوات التي صنعها لمساعدته في اعماله ومحساو لات لاكتشـاف الاشياء،" ويمكن عد الادوات الحجرية الاولى انجاز ا تكنولوجيا ونفعيا وان كل اختراع هو اقتطاع قطعة من المجهول وتكيفها بتغير الثكل حسب حاجات الانسان وهو ما يفعله الفن كوظيفة تطبيقية "؛ ، ولقد وجدت التقانة منذ بدايه الانسـان البدائي و التي حملت في جو انبها كيفية التدخل الانسـاني الذي كرس نفسـه لتغيير حياتهـ و اكتشـاف ادوات جديد

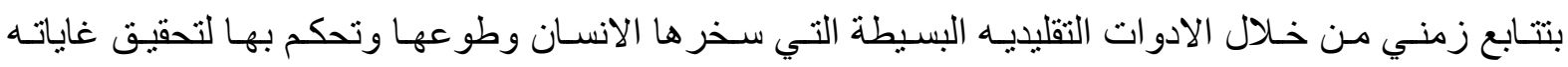
الاجتماعيـة والفكريـة والتي اصبحت تعبير ا عن وجـوده والتي جعلت من هذا الموجود الانسـي سيدا على

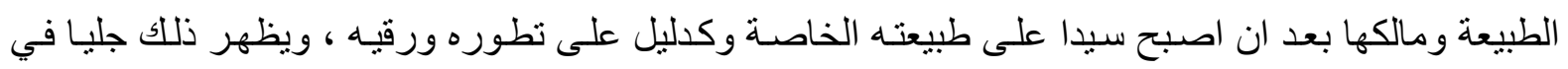
الادوات و الالات البسيطة التي طوعها واستخدمها لتلبيـة متطلبـات حياتـة اليوميـة ،" لهذا فالتقنية هي العنصر الرئيسي الذي تحدد وجوده ولايجوز القول انها العنصر المستقل في حضارة البشر ،فالتقانة اذن اكتشفها الانسـان و استعملها من خلال تحديد وجوده" ، لذلك نجد عند البحث في نشأة التقانـة الرجوع الى الجذور التاريخية لهذا النشاط الانساني وان اختلفت دو افعه وقيمـه الجماليـة " فالتقنيـة لم تتطلق هكذا الا ببطئ. ثم تسـارع تقدمها هذا التقدم الذي سيلم به ايضا بعض فترات من التباطئ لكن التسـارع المستمر ادى الى تحولات كبرى في مجرى

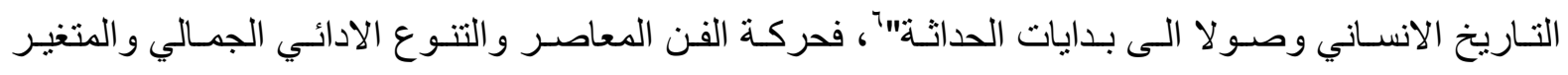
الاسلوبي، هو امتداد تاريخي لحركة الفن عبر التاريخ، وان ارتباط الفنان بجذوره القديمـة واهتمامهـ بالتقنيات و الخامات التي نفذ بها الثواهد الفنية كما هو الفن القديم في ارض وادي الر افدين والاهتمام بالاسـاطير و التعرف 
على الطبيعة والظو اهر الاجتماعية، بعدَّ وادي الر افدين مهد الحضار ات و الانجازات الفكريـة والجمالية ومركزا مهما في الفكر و الابداع ـ اذ تعامل الفنان باختر اع التقنية من محيطه و اعاد للطبيعة صياغتها "فالتقنية اكتشفها

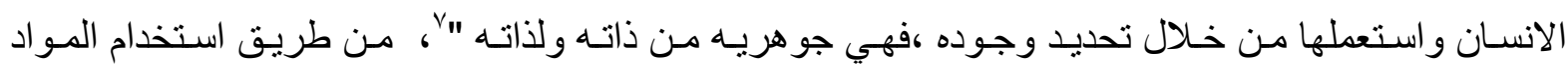
و الخامات المتوفرة من حوله من طين وحجر وصبغات من مصادر مختلفة نباتية وتر ابية و عظام الحيوانات . وكما استخدم الانسـان التقانة في العصور الحجريـة لجدران الكهوف وسقوفها كسطح للرسم استعمل فيها شحوم الحيو انات للحصول على مصدر ضوئي يسـاعده في تنفيذ رسومه كما استعمل اللون الاسود من السناج(*) كما استخدم الانسـان البدائي (Primitive) الكثير من الخامـات كالعظام والأحجار وفروع النباتئات التي كانت بحد ذاتها عملا فنيا وساعدته في أعمال الرسم على أسطح الكهوف التي عكست طبيعة مخاوفه من

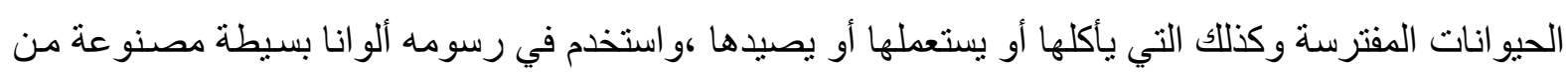
الأتربـة الملونـة يقوم بتحضير ها بمواد كالمـاء و الدهون مستخدما يديـه و أحيانـا أوراق بعض الأشتجار كأدوات

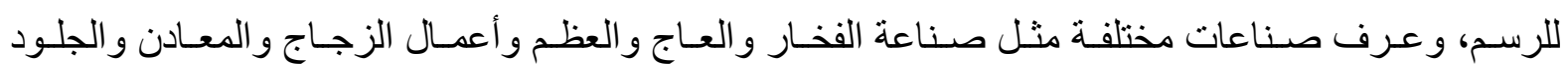
والمنسوجات و الأحجار والأخشاب، غايته الرئيسية المحافظة على استمرارية العيش البعيدة عن المخـاطر التي كانت تو اجهه منثل فيضـانات الأنهار - كوارث طبيعيـة- حيوانـات مفترسـة، رسم الإنسـان البدائي على جدران

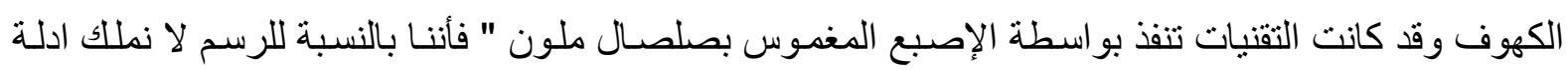
مؤكدة لتحديد الاداة، ولكن من المحتمل جدا انه استخدم اصـابع اليد وجلود الحيو انـات ذات الفراء او حزمـة من شعر الحيو انات وربما ريش الطيور بمثابـة الفرشاة في انجاز رسوم" ^ فقد عثر على رسوم لجداريـة متعددة الألو ان (في كهف التامير ا)(*)، يوجد بها تقنيات مركبة من الزخـارف و النقوش ،التجاويف المحفورة بفضل

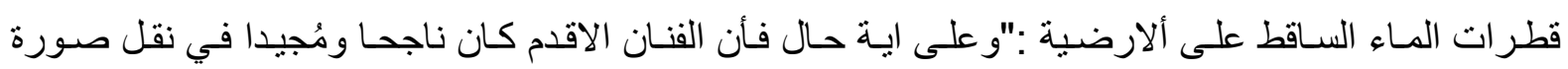
الحيو انات التي عاشت بقربه فهو ينقل لنـا وبشكل معبر حقيقي يعتمد على الصورة التي تتقلها العين المجردة

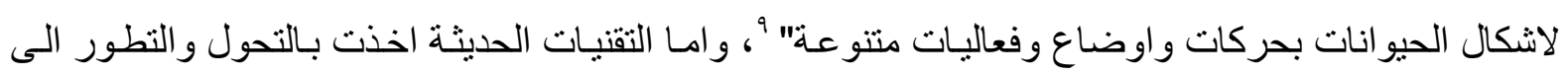
مفهوم اغنـى واعمق من خـلال تحولها الـى شيء مستقل عن الانسـان وتداخلت التقنية في كل جوانب الحياة الاجتماعية والفكرية و الصناعية "و التقنية بالمفهوم الحديث هي تطبيق معطيات علميـة معينة مـن اجل الوصول الى نتائج محددة ،كما تشير الى مجموعة من السلوكات العملية التي تستعمل المعارف العلمية لكي تحرر نتائج معينة "·'، و وان التطور التقني الحديث افرز عن الكثير من المفاهيم المعرفية والفلسفية كانت افرازاتها ونتاجها نتاج هائل من الوسائل والاكتشافات والاضافات لتجعل من العصر الحديث عصر ا صناعيا وتقنيا في كل شيء منيء في المجتمع الاستهلاكي وفي السـوك الاجتمـاعي " فقد قدمت التقنيـة على مسـتوى السـعي الكينـوني للعقل الانساني في تحصيله للمعرفة التي تعادل حنينه العميق المتجدد للكينونـه " (1) و واصبح للتقنية مفاهيم معرفية و إيديولوجية تسعى الى تضمين كل شيء في الوجود الى سلطتها ، فالطفرات و التغييرات و التحو لات التي حدثت في الحضارة الغربية بعد نهايـة الحرب العالمية الثانيـة والاتجاه نحو مجتمع مابعد التصنيع وثورة المعلومـات وسيطرة التكنولوجيا والالكترونيات ،ساعدت في تحويل العالم الى قرية صغيرة " فالطفرة التقنية تجعلنا نواجه عالمـا تعجز مفاهينـا التقليديـة عند استيعابه ولعل اهم مميز اتـه التفـاؤل الذي اخذت تعرفه اهميـة المكان ليغدو 
الزمان هو كل شيء وليحل الوجود الآني والزماني في الأمكنة المتعددة محل الابعاد المكانية " r' فكان لابد من هذا التطور الكاسح ان يؤثر على الفن والتشكيل ،ليولد مدارس واساليب واتجاهات بتقنيات متعددة ولها تاثير في تاريخ وحركة التشكيل والاتجاهات النقدية المعاصرة والاتجاهات التأويلية في تأويل تقنيات اظهار مـادة التشكيل في المنجز الفني التنكيلي ، و وامـا العمل الفنى فهو تنظيم جمالى يحمل فكرة يجسدها الفنان باستخدام أسس و تقنيات مقصودة تفصح عن مدى التوافق بين الامكانـات التقنية و التعبيريـة للعمل الفنى و اظهار الفكرة التى يسعى الفنان لتحقيقها ، فللتقنية دور اساسى فى العمل الفنى ، لأنها تمثل الخبرة و القدرة على تجسيد الأفكار

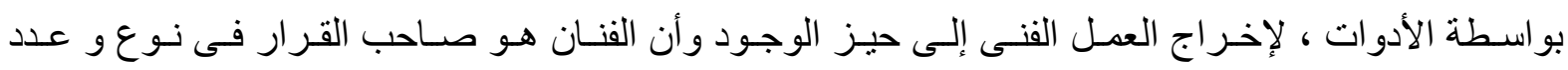

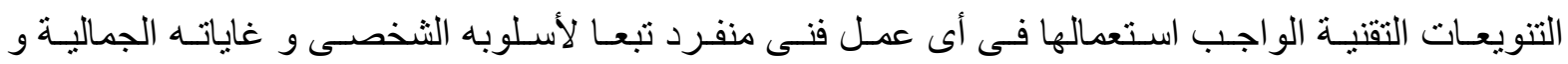
التعبيرية، فالتقنية عملية مركبه فمنذ بدء اختيـار الفنان للخامـة و القيام بعملية الأداء و التنفيذ "فامتز اج العلم بالتقنية ،بل خضوع العلم للتقنية ،اي لاعتبار ات الاختيار و الانجاز والتطبيق و المنافع و المردوديـة على حسـاب

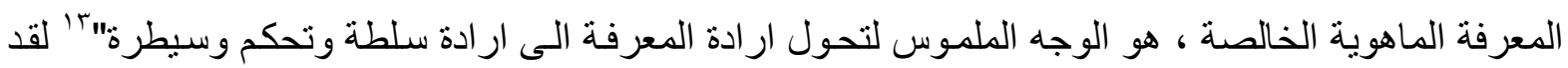
كانت القتنية سابقا مرتبطة بالجسد وليس بالفكر بخلاف الانسان الحالي المعاصر الذي ربط التقنية بـالفكر لانها كانت وظيفة لاطبيعيـة اي اجنماعيـة واصبحت ذات طابع صنعي على خلاف تفكير الفنان الانسـان المعاصر الذي اذكى التفكير والاكتشـاف كمـا يعبر بروتـاغور اس عند محساورة افلاطـون "ان الانسـان مقيـاس الاشـياء كلها" أ. وقد تغير مفهوم التقانة منذ بدايات الفن الحديث مـع التقدم العلمى و التكنولوجى و الصناعى في مجـال إنتاج الخامات و الأدوات التى زادت من القدرات الإبداعية للفنان فى التعرف على خاماتـه حتى أصبح مرسمه مليئ بالعدد و الأدوات اليدوية و الكهربائية و التكنولوجية ، مما أضفى على القدرات التشكيلية و التخيلية للفنـان أبعاد و رؤى جديدة أصبح من الضرورى معها الوصول الى اسـاليب وتقنيات مستحدثة تناسب التحول السريع

للعصر.

المبحث الثاني: الجذر التاريخي في الرسم العراقي المعاصر. ارتبطت الحركة الفنية بالعراق بماضيه الذي تمثنل في فنون عصر قبل الكتابـة في فنون سومر واكد

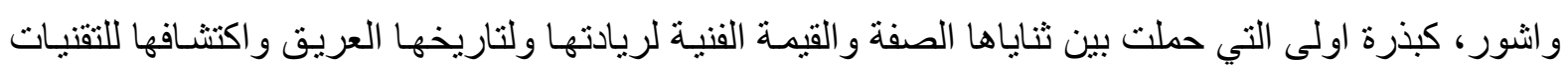
المختلفة والذي امتدت اثاره الى الزمن اللاحق، التي تغلغلت فية التجارب الر ائدة بتفاصيلها التي اشتقتها من البيئة المحيطة كمرجع ومنطلق للفن في العراق، و يمكن ان نفهم ان تقنيات الفن عبر التاريخ و العصورمرتبط

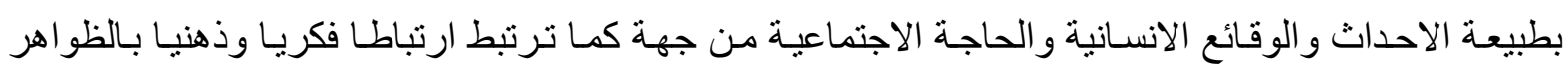
الفنية التشكيلية من جهة اخرى كمحصلة للفكر الحضاري الذي خلفه للاجيال القادمة . "فقدعبر الفنـان عن كثير من وجوه الحياة الحربية والاجتماعية والدينية ووجد هذا الفن مجالاته على سطح اللوحات و الفضـاءات الاخرى

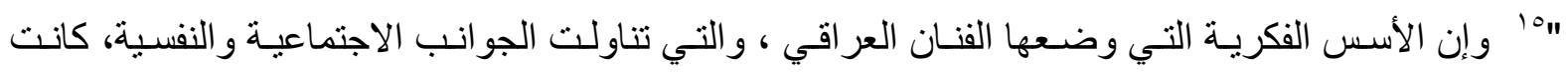
تتضمن قضية الفن بالمعنى الذي تجاوز الأطر الاجتماعية المحدودة. كانت هذه الأسس اعتمدت تجسيد وخلق ولق

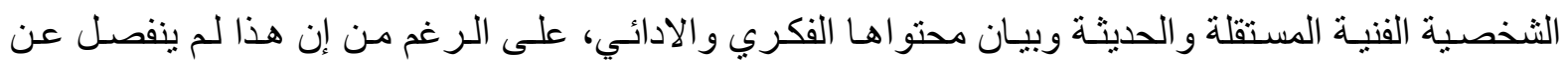
التيار ات الفنية العالمية الحديثة التي تمتاز بالتفرد و التجديد، كما ظهر في الفن الإسـامي الذي تميز بخصـائص 
فريدة تجعله ذو طابع خاص عن بقية الفنون الأخرى من ناحيـة التجريب في التقنيات مثل الاربسك العربيالذي اهتم( بالمو اضوعات الدينية كالمساجد وزخرفة الآيات القرآنية، واعتماد البساطة والتجريد والابتعاد عن الترف

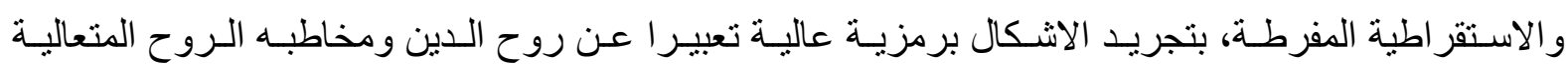
وتجسيدها، وتميز ايضـا بالوحدة الفنية في المظهر والجو هر على الرغم من التتوع الثـديد الذي يتمتع بـه، وبعد ذللك انصـرف الفنـان للتعويض عن التجسيم، و الاستعاضـة عنـه بـالتلوين و التـذهيب ، وهذا أدى إلى ظهور الرسوم التوضـيحية ( التسطيحية ) و الصـور الصـغيرة (المنمنمـات) Miniature ، وهي "عبـارة عن تزبين

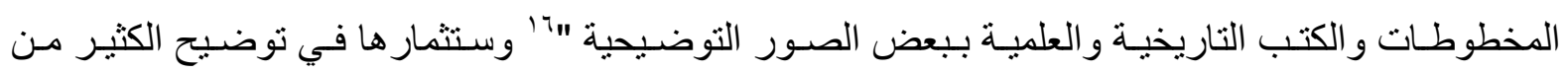
المخطوطات الأدبية و العلمية و التاريخيـة و دو اوين الثـعر بالصـورة الصغيرة، هذه الرسوم سجلت لنـا الحياة الاجتماعية بالصورة من حيث الاحتفالات و الأزياء و أنواع التحف التطبيقية و العمارة، في صورة مزخرفة دوة ظهرت بشكل مخطوط اشتهرت بها المخطوطات الاسـلامية تمثلت بخصسائص مميزة تشـمل الجوانب التقنية و الأسلوبية والوظيفية التي يطمح إليها هذا التصوير، وقد ارتبط هذا النوع من التصوير بتطور المخطوطات

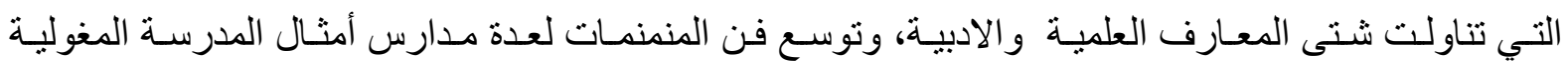
و المدرسة التيمورية، ثم المدرسة الصفوية والمدرسة المملوكية و المدرسة التركية و المدرسة الهندية، ثم المدرسـة المعاصرة ، فالمدرسـة البغداديـة "يطلق عليها اسم بغداد، كمـا أطلق عليها بعض المؤلفين المدرسـة العباسية، ومنهم من أطلق عليها بـلاد الجزيرة(الميزوبوتاميـة)، أو (مابين النهرين) لأنها نشـأت بين المسيحيين في بـلاد

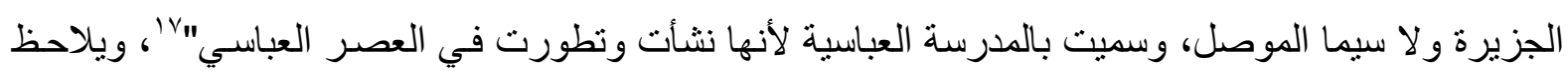
في فن المنمنمات بوضوح الخروج عن الواقعية الحرفية عند مقارنه حجوم بعض عناصر اللوحة الى العناصر

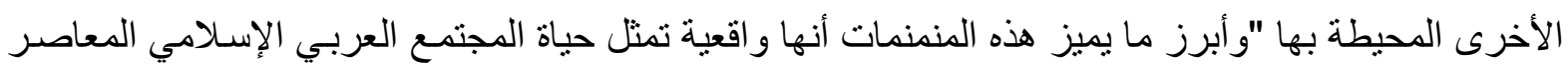

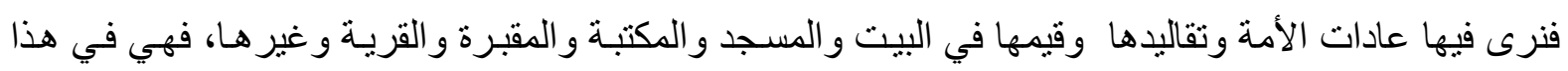

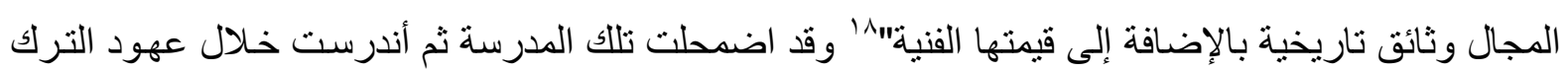
في القرون الاربعة الأخيرة، وانقطع ذكر هـا، وقد جرت محاو لات لإحيائها في القرن العشرين على يد الفنـان جو اد سليم في الحركات الفنبـة التي ظهرت في العراق في مرحلـة التاسيس، فالفنـان في هذه المرحلـة لم يكن

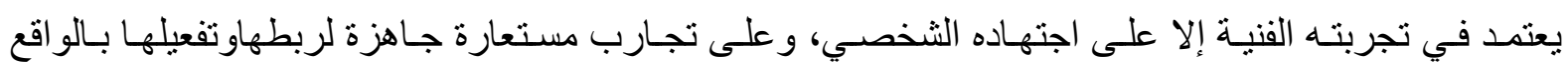
الاجتماعي، بالتالي فإن انعكاسات الأبعاد الاجتماعية كثف أيضاً عن نمط تفكير الفنان أو نظامهـ التعبيري الذي

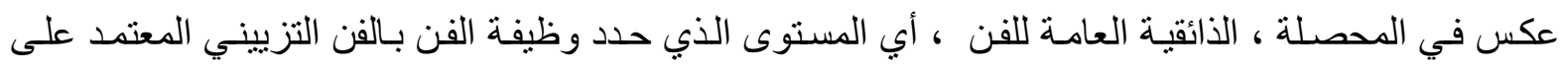
المحاكاة في الدرجـة الأولى. و هذا المسـار لـ يحدد هويـة الفن العر اقي و اغنائهـ بسمات وخطساب الخصوصية

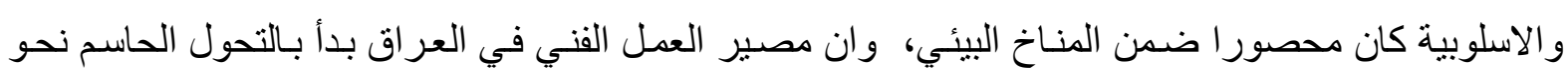
مرحلة جديدة تتسم بالاعتماد على النفس والبحث عن ملامح الثخصية الحضـارية في التقنية و الاداء و البحث عن المصدرية التي ترسم اهدافه وتجعل له اثرا بليغا وبالغا في اكثر من حقل ترسم خطـاه، من خـلال ظهور

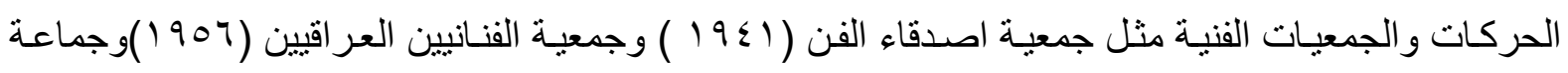


الرواد التي ساهم في انشاءها فائق حسن ( 900 190 ) وجماعة بغداد للفن الحديث التي اسسها جواد سليم ( 1901 ) وجماعة الانطباعيين التي مثل حافظ الروبي قطبها ( 190 ( ) ).

تطورت التقانة في اسلوب الرسم العر اقي منذ اواخر القرن التاسع عشر على ان الفنان كان بطبيعة ميالاً الى رسم المنظر الطبيعي و غنى التجارب، و نستطيع ان نتلمس ذلك في دراستتا لتقنيات وثقافات الجماعة

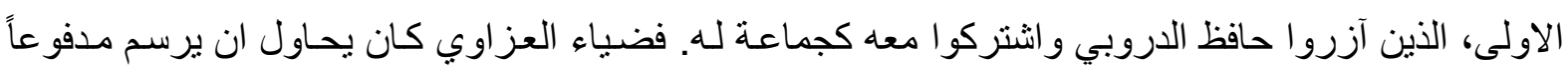
بحسه الاثاري في البحث عن المحيط، مخبأ الكنوز الحضارية، وسعد الطائي بوحدة الانسان مـع الطبيعة، وحياة جميل حافظ بحسـها الثـعري واحساسـها الفطري بجمـال الطبيعـة الزراعية، وحـافظ الدروبي نفسـه بحبـه للبيئة الاولى مرنع طفولته، على ان ظهور الجماعة كان من طرف آخر يمثل الحماس، حمـاس المثقف العر اقي نفسـه و اكتشاف ذاته " فمعظمه كانوا من الثباب الجامعي في العراق، وهم ينهجون الى دراسـة الفن بروح جديـة، وشر ارة الطرح الحضاري في الفن كما بدأتها جماعة بغداد للفن الحديث تسري السى هشيم الجماعات الاخرى. و هكذا كان لجماعة الانطباعيين العر اقيين اذن موقفهم القومي في الفن العراقي في الخمسينيات، ونستطيع ان

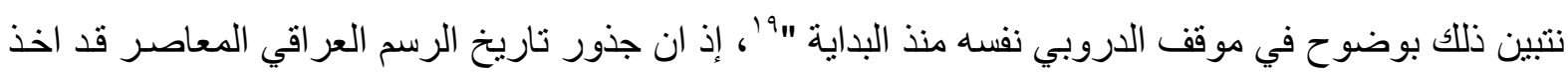

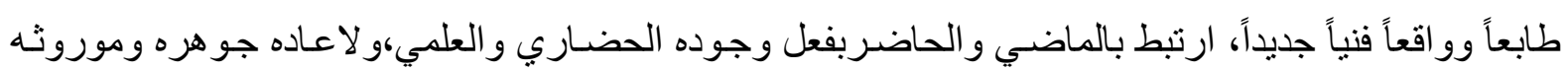

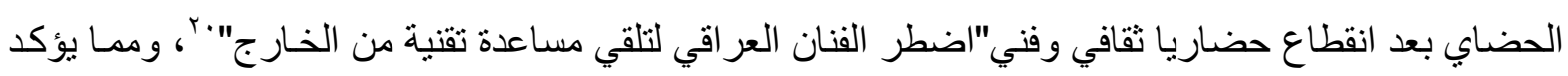
ويفصح عن هذا الو اقع هو" تحول غير مباثـر او مرئي في دور الفن، فـاذا كانت التقنيات الفنية الثعبية هي

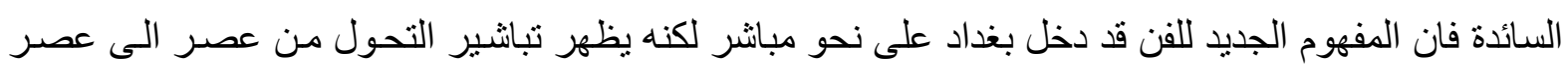

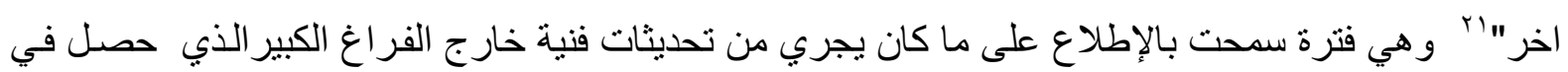
الفن والحضارة، وان الوقوف مليا عند سمات المشهد العر اقي الساخن يكاد يعطي تفسيرا جليا لوحدة الروىئ للى بـ اغلب الفنانين التشكيليين رغم أختلاف اليات التعبير التي تجمـع مـا بين التأثر بـالفكر الغربي ومن ثم العـالمي والبحث عن الثخصية او الطابع المستقل عن الملامح الاجنبية في نفس الوقت،هوقد بدأ واضحا ان بالامكان الجمع مابين كل من التقنية والاسلوب الجاهزمن طريق الاكتشاف و الابداع الفني، وهذه هي مهمة الفنان الذاتية، ومسؤوليتة الثخصية التي اخذت تبرز وتتبلور وتتمو تقنيا باتجاه الاختز ال والتبسيط للاشكال الطبيعيـة وتحقيق وهن هنيق اختزال المساحة والكتلة الى التجريدية ( الصورية )، ودخول الحروفيات الذي نجده في اعمـال جميل حمودي

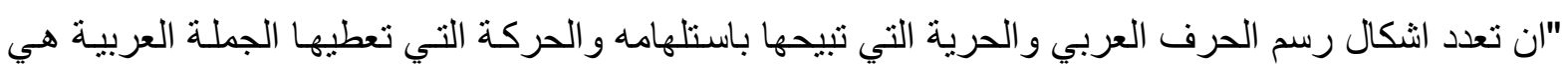
مجمل مايشغل بال الحروفيين ...ليست لحروف الدالة على رموز لغويـة وحسب بل هي قيمـة تشكيلية اندرجت ضمن اعتبار ات الثكل الفني مابين تحقيقين زخرفي ( ساكن ) وكتابي ( متحرك ) نجد شيئًا اساسيا في لوحات

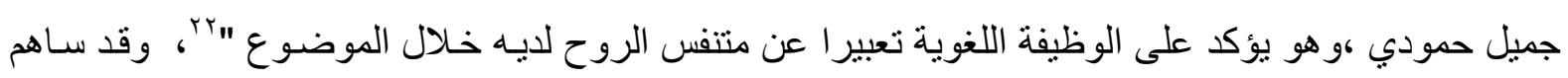
شاكر حسن بدور كبير في ارتقاء الفن التشكيلي العر اقي بما قدمه من إسـهامات فنيـة وتنظيرّيـة، من أجل تحقيق أساليب فنية مستقلة عن تأثير الأساليب الغربية. أن شاكر حسن آل سعيد مربتحولات عديدة باتجاه تأصيل رؤيته في الفن، ومنحه قيمة إنسانية خاصة. ويعتبر الر ائد الوحيد الذي حافظ على ربط نشاطه الفكري بفنه. عبرَّ فكرة ( البعد الواحد )، و هي تعني مرحلة التشخيص والاهتمام بالفلكلور، وثثم مرحلة التأمل حيث يتخذ التجريد أسلوباً 
له ، وبعدها يدخل الحرف كجزء من مضمونه ومن بنيته التصويرية. و أخير اً كان اهتمامهـ بالسطح الخـارجي للوحة، أو تصدويره الجدار. ثم الى التجريد. ويقول شـاكر آل سعيد في كتابه ( الفن بستلهم الحرف)، " تعبر ممارسة الحرف العربي، و الحرف عموماً، في التشكيل الفني عن محاولة للعودة الى القيم الحقيقية في الفن. أي التي تعني استقصـاء الحقيقة في الفن ومهع ذلك المحافظة على المعنى التشكيلي في البحث بو اسطة الأبعاد. فالتعبير بالحرف أذن هو محاولة مشروعة وتطور تاريخي للفن ونحو تخطي الو اقع السطحي ذي البعدين كمناخ طبيعي للعمد الفني الى حقيقة الخط أو البعد الواحد، أو البعد (الحركة النسبية) أو الحركة العقليـة أو الرؤيـا

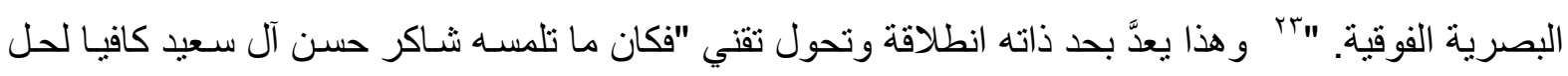
مشكلة تمثيل الأشكال و الإيحاء بأوضاعها، وأبعادها، وأحجامها، وان الخلط بين تللك التقنيات الثكلية المتعارضــة جعلت الأمر معقدا، فقد قام بخلق فضـاء غامض ومضـغوط بقصدية، فكان يحاول (تركيب) أسلوب منظوري و همي متعدد الزوايا (اتجاهات النظر)، يحدّه في ابعد نقاطه عن المشـاهد جدار يجعل الفضـاء مقعر اومشـابها لفضاء علب السردين، والبيوت الزجاجية للأسماك، فتبدو أثكاله فيه طافية في الفضـاء كالأسماك، على أبعاد أبعاد

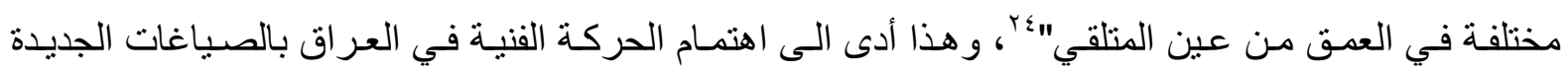
و التقنيات و النزوع نحو تجارب الرؤية المستقبلية و اكتشاف معالمها الابداعية. المبحث الثالث: تقتيات الاظهار في الرسم العراقي المعاصر(جيل الثمانينيون والتسعينيون ).

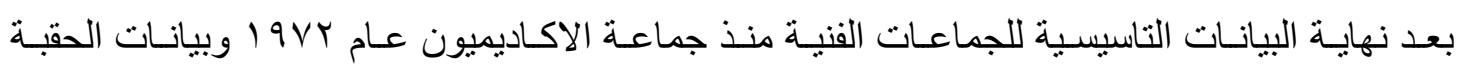

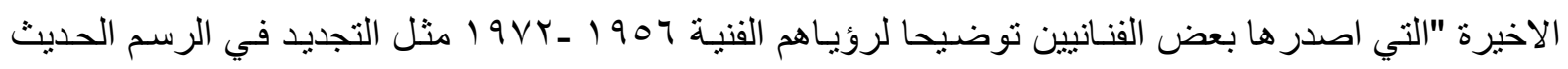

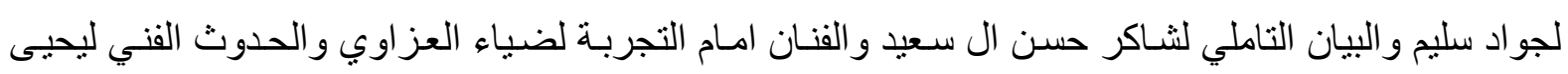

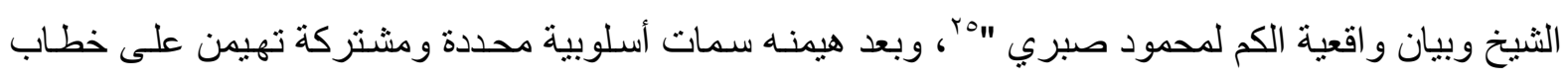
حقب فنية وتتعاقب زمنيا في الرسم العراقي، استعارت الكثير من الخـارج بتقنيات ومفردات ووحدات اسلوبية، اثرت على الطابع العام للاعمال الفنية في الرسم العراقي ، ففي منتصف الثمانينات ظهر (جيل) من الرسـامين

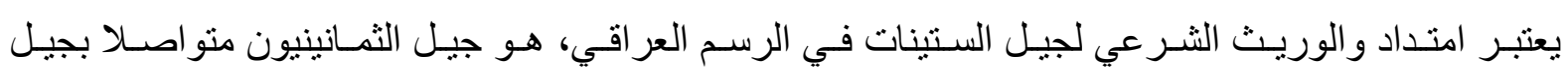

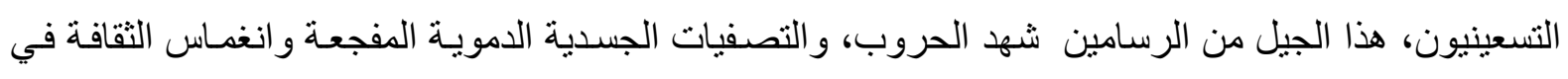

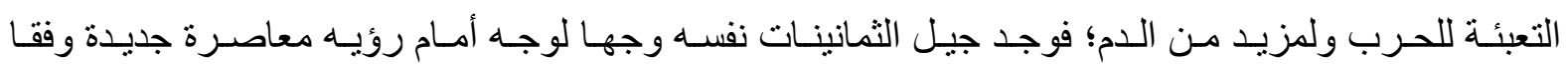
للمتغير ات التقنية والايديولوجية التي يمر بها العالم ومو اكبته.و أمام الحاجة الى متغير في الاتجاهـات و الاسـاليب التجريبية والتخلص من قداسة الموروث و التبجيل المألوف السائد، لقد آمن جيل الثمانينات، ولو بدرجات متفاوتنة بـ"أن الرسم بطبيعته الإنكارية يقيم اتصاله بماضيه عن طريق الانفصـال، وأن أي تحول فني لا يولد في رحم

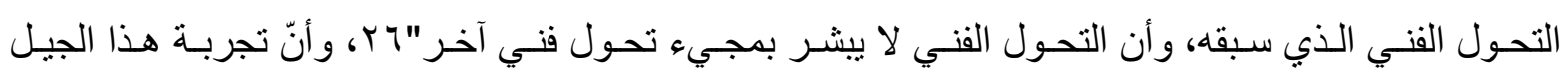
الحداثوي وظف التقنية والاسلوب الثخصي من خلال التوفيق بين (المحلية) وبين التيار العالمي للفن وقد صنع

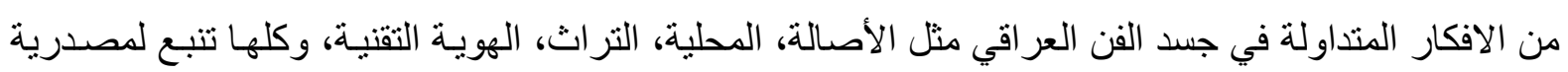
الخصوصية و التفرد و التجريب. 
لقد كانت جذور تقانة جيل الثمانينات واحدة من الاستنادات الفكرية الجمالية في الرسم العر اقي، وكانت نابعة و مستتدة على تجربة الجيل الاسبق(التأسيسي) أمثال طروحات شاكر حسن آل سعيد في (التعريـة الثيئية) التي جمـع آل سـعيد شتناتها في ثنائيـة اسـماها (التعريـة ـ التر اكم)،" فكانت التعريـة مفهومـا كونيـا حيث كانت الطبيعة تتعرى بفعل قوى المناخ والقوى الفطرية لها، وقد اتخذت تعريفـات مفهوم التعريـة عند آل سعيد أنشكالا

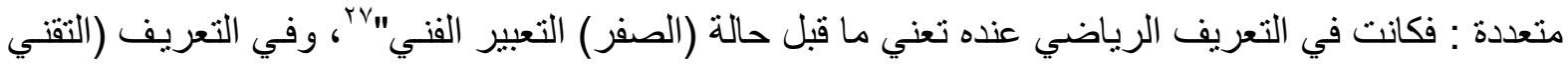
ــ البصري) تعني عنده "عمليـة (تعريـة) ذات قصد معين وليست عفويـة تحدث بقو انين الحيـاة الماديـة كالتي تحدث في جغر افيا الأرض" ${ }^{\prime}{ }^{\prime}$ و هو يعطيها بعدا شيئيا حين يعتبر ها "معرفة متحققة في الظاهرة الثيئية وليس بو اسطتها، ويصبح من دعوى الالمـام بـالوجود الثيئي، فهنا التعريـة (كحالة) أساسية في (إغناء) المظهر بمـا يحتويه من آثار وفي معنى الأثر"ج" ، ويعطي شاكر حسن آل سعيد التجريد بعدا صوفيا ودينيا باعتباره "تخليا وتجردا وتركا وخلعا للمطامع البشرية" ·־، وقسم شاكر حسن آل سعيد تقنيات التجريد إلى نمطين همـا : تعريـة

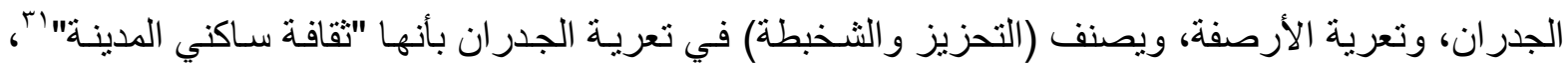
ويفترض بثقافة ساكني المدينة توفر حوار متبادل بين تلك الجدران وساكني المدن؛ بينما يصف تعريـة الأرصفة بأنها اكتفاء للعمل الفني بذاته فهي ناتج ما تضيفه الصدفة إلى اللوحة من مؤثرات وما تسلبه منها و إنها "تحزيز

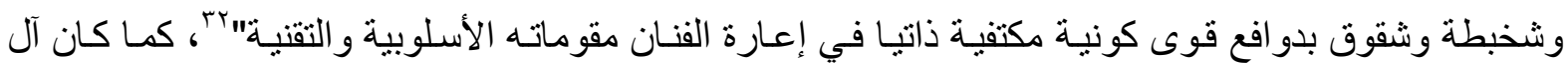
سعيد يحاول اكتثاف الطاقات الفاعلة في الوجود المحيط، تلك القوى التي تتجسد منتقلة من طبيعتها الجينية إلى طبيعة تقنية و هي العناصر ( الماء، والهواء، والتراب، و النار) فكان الماء عنده يتجسد تقنيا عند معاملة اللوحسة ومـا عليها من ألوان بالمـاء بحيث يظهر تأثيره على مستقبل اللوحة، أو باستخدام السيولة في التقنية اللونيـة، ويتجسد فعل النار في فعلها الذي يؤدي إلى نشوء فوهات بواسطة الحروق، والتراب يظهر في إسباغه طبيعته على عجينة الألوان، وأخيرا يظهر الهو اء من خلال الألوان التي تسقط على اللوحة بطريق النفخ. وأما في بداية الثمانينيات ظهر تجمع (جماعة الاربعة) وضم كل من فاخر محمد، عاصم عبد الامير، محمد صبري، حسن عبود وكان سعيهم لاضفاء وسائل نو عية لتطبيع العلاقات المنبادلة مع الذائقية الجمالية من خـلال

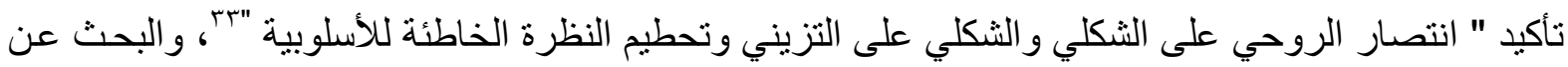
المتغير الاخر في انساق الاسلوبية وعن المخفي وغير المتوقع في منساخ يحرره من آلياته السـائدة الملاصقة الثابتة. فحملت ذاكرة الرسم العر اقي المعاصر ، الكثير من الاسماء المتميزة، وتداخلت منجزاتهم الفنية، مـع القيم الجمالية من خلال قيمة الاسلوب الفني والخصائص اللونية والتقنية. وان مايتم انتاجه بعدَّ في احد معانيه يعني

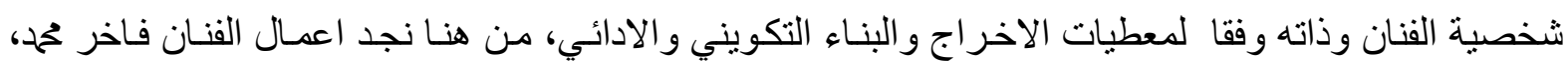
يمتد في العمق، على وفق مستوى البناء السطحي ، و هو المستوى الذي يؤسسه آلية واداء الألوان، وفي الفضـاء العائم ترتكز ألو انـه بمحيط المفردات والعناصـر البنائية بآثار اوبقعا وسو ائل مسكوبة، وهذا المستوى يعالجها الفنان بخيـال و اداء الصدفة كما يحدث عند جاكسون بولوك بطريقة التقطير وسكب الالوان، لمعالجـة الناحية الزمنية، بمستوى غائر يمثل بقايا حياة زمنية من جدار أو تراث قديم دونت جغر افيا الرطوبـة والتعريـة عليها آثار ها، ويمكن أن نتلمّس الامتلاء الواعي غير المحدود بموجودات الواقع و الزمن في أعمال فـاخر محمد، منلمـا 
هو عند هاثم حنون وكريم رسن، بتوظيف علامات يومية و محتويات الذاكرة التي ينم استعادتها من مخزون الحياة المتأكلة، إنها (المادة الجوهرية) التي تملأ ذاكرتهم وتغذي الخيال لافر از الجمال الفني الذي تحمل المزيد من الانشغالات التعبيرية، وأن النسق الدلالي في اعمال عاصم عبد الامير "هو الأساس في مجمل لوحاته وكان يسند بـالمفردة دلالات على شكل حقول ومحاور ليكمل عملية الربط ولا يترك فضـاء اللوحسة، إلا ويشرح للك الكيفية التي تدرك من خلالها كمتلقي نتاجه من خلال علامة أو مجموعة علامات ، يقابلك بفرضيات يريد منك ان تتلقى النسق بكل استرخاء وما عليك إلا أن تحساول من خـلال العلامـات و الحقول الى الكثف عن الوحدات المؤولة تاركا النسق في حالته الأولية، وربمـا تناقض المفردة نفسها ولكنك بمقام سيميائي يجب عليك التسليم بوجود الحقول و المحاور سو اء كانت تكاملية أو تناقصية، ولكن الرسـام يعلن تحقيقه التوازن بطريقة مسلمة

امـا تجربـة حسن عبود" فقد عمد على تحطيم الثكل لصـالح ان نعيد تامل الاشياء مجددا من زاويـة اخرى. انه لا يرسم الاشياء كما تر اهـا العين بل بالحدس. فالجسد البشري في لوحاته يكون شكلا عامـا للعمل الفني. وتكمن الاشياء الاخرى في داخله. فتتلاشى عنده الذات بالأشياء وقد وظف حسن التقنية لصـالح البعد الجمالي" "إ، فهو يعمد في صنع نر اكيب بصرية محدثة في تصور اتها الجمالية من تلقاء المخيلة مع انفتاح معقلن على ارث وثقافة الاخرين، و إنتــاء خطابـا مؤطر بتجربـة وتر اكم معرفي لخلق نوع من الاحداثيات المستقلة و إرساءها في ذائقية المتلقي من طريق الجوانب التصويرية للتكوين. شخوصـه محاطـة بهندسية حادة حتى انها كثير ا ما تتمحور داخل المربعات التي تحيطها" ينو غل في عفويـة الأشكال و المفردة هكذا يوظف حواراته ، و هـي تحـاول أن تكسر عزلتها أو حدة الأشكال وصـلابتها ، لتنفلت في فضـاء اكثر بهجـة و بتدرجات لونيـة متناغمة لتؤسس نور ها من تركيب لوني تتابعي . إنها رحلة يساير ها وهي تتحرك على القماش باعثة حياتها ، منتصر الها وبشفافية عالية وبلمسات منقنة تبرز الكائن وانعكاسـه الروحي، و التركيز على الكتلة كرمز بنائي يحيل إلى مساقط ضوئية ، معتمدا على انسيابية الخط وبلورة الثكل و المساحة الممنوحة لخلق الششهد وتفاعلاته

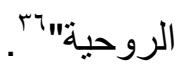

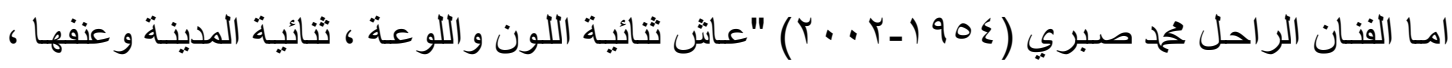
ثنائية التذكر و النسيان ،المو اجهة و الصمت ثنائيسة المبدع و اللاجدوى ـ فنـان حاول جاهدا أن ينزع عنه أنقال سنين عجاف ـ يطارده الحنين إلى زمن الألفة ، الأصدقاء ، التجريب ، اتصفت أعمال الفنان محمد صبري بالو اقع الذي طالما أدرجه في مخيلة المتلقي ، تكون تجانسا لونيا معبر ا على إدهاش المتلقي ، وبمعالجة احتر افيـة واعية لمسـاقط الظل و الضـوء، يجزئ محمد صبري مسـاحة العمل إلى أجزاء داخل اللوحسة وينفذ وجوهـا محفورة في تركيب لوني أبيض أثباه مايكون بكتاب تتلاحق حركة أور اقه كأجندة لذهالة الوجوه، أو يرسم شخوصـا بضبابية وكأنها تتحو برمزيتها نحو ثنائية الحياة والموت" لَّ، كان معرضه الأخير في قاعه حوار نسيج اخر مغاير بتقنيه منفردة تكاد تكون الاولى من نو عها في التجريب وتقنية الخامات بتعبيريه تجريدية وانعطافة في اعماله واسلوبه بتجريب الاحبار و المو اد مختلفة وبرؤية معاصرة . 
واما في تجربة هناء مال الله، فعندما كان شـاكر حسن آل سعيد مأخوذا بحوار (تقنية الجدران) كانت

هنـاء مـال الله مـأخوذة بـالنمط الآخـر مـن التقنيـات التجريديـة، بـالحوار الصـامت لسـاكن المدينـة مـع الأرصفة

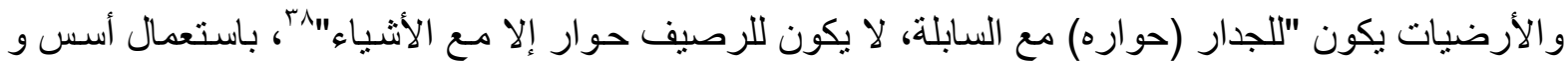
تقنيات مقصـودة تفصـح عن مدى التوافق بين الامكانـات التقنية و التعبيريـة للعدل الفنى و اظهار الفكرة التى يسعى الفنان لتحقيقها، و هناء مال الله ثابرت في مواصلة بحثها عن بين التشخيص وبين التجريد الذي سيثكل رؤية حياتية وفنية، فضـال عن توظيف النفايات ومخلفات الحروب ومـا لها من تأثنيرات نفسية ذاتيـة في حياة الانسان عامة والمتلقي المثقف خاصة، وقد تعمق هذا الاتجاه بفعل القناعات و ووجود ورفقة أستاذهم ومنظّر هم شاكر حسن آل سعيد." لكن هناء وعن قناعات تلبستها منذ البدء لا تزال تحاور تضـاريس العهل الأثري وبكل عتمة طبقاته وحتى تجاوز الأثر مستحدث مستقطع من وسطه المحيط، لكنه منتقى بعناية ضمن نفس ذلك الحس الأثري، و لا يز ال مستحكم في سطوح اعمالها كنصوص تشكيلية مكتفية بكفايـة فاعليتها، وكأحجية كثير ا مـا تكون صوفية تحاول ان تتكثف عن انتهاكات بيئية، هي الأخرى اثريـة متصورة." "جَّ، لقد كانت تجربتها الفنية

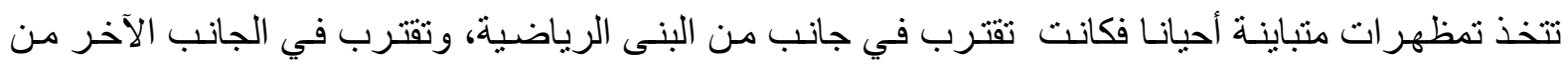

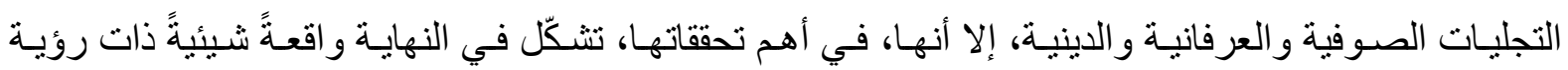
متُحفية اركولوجية ارتبطت بـالحفر عن فعل الزمن في التحفيات العر اقيـة الر افدينية القديمة، واهتمامها وأبنـاء جيلها بالسطوح، والجدران، و الأرضيات في شوار ع بغداد التي كانت الرسامة تتبناها، وتسجل فعل الزمن فيها، و هو ما نبّه أبناء جيل الثمانينات في الرسم العر اقي إلى تقنيات حديثة على سطح اللوحة بـالخرق، والحرق، و التلم، و التخريم، و التخريش، والتحزيـز، و الثـخبطة، وعمل الاخاديد و التشقيق، التـي كـان آل سـيد يسميها المعارج: " ومـا إلى ذلك من مؤثرات الخراب و الحرب الذي بـدأت هنـاء مـال الله البحث فيها، وكانت تر اهـا استر اتيجا بصريا ـ تقنيا مؤثرا في الرسم العر اقي أسمته، في بعض كتاباتها ومحاضر اتها التي ألقتها في لندن حيث تقيم الآن، (Ruins Technique) أب (تقانة الخراب) الذي تراه خرابـا حيويـا Vivid Ruins ) يثكّل أهم المؤثرات المهيمنة في الثقافة العر اقية بعد الخراب الضخم الذي تعرض لـه العراق و الحياة والثقافة

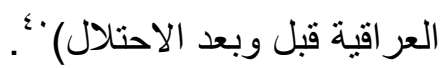

اما هاثم حنون يوزع أثكال لوحاته ومر اكز التقل فيها اعتمادا على تقسم السطح التصويري للوحة الى منطقتين تبعا لدرجة قداستهما، ممـا أنتج بنيتين هيكليتين متجهتين هما:الموت و الخلود" لقد كان هاثـم حنون رساما تعبيريا حتى حينما يكون في اشد حالاته غلوا تجريديا بسبب كونـه قد اعتمد اختز ال أنثكال المشخصـات

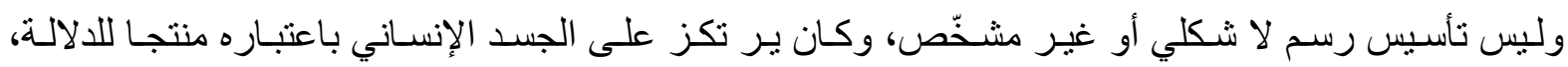
وللتو اصل، عبر استنطاق أعضـاء الجسد ذاته أو امتداداته، فكان قد اتخذ الجسد كلا متكاملا كـهيمن شكلي يؤسس عليها معمار لوحاته، جاعلا أعماله تلك مشبعة بإيماءات الجسد الإنساني من خلال مـا تم التموضـع عليه اجتماعيا من دلالات" اء ، وأشكالا تعبيرية مشخّصة ومحتفظة بملامحها الطبيعية بشكل كبير مع احتفاظها ببنية الزمان و المكان،بأستعمال مو اد متنو عة من كارتون محروق وورق وصحف و اسـلاك واحبار وغير هـا لتوظيفها بتقنيات معاصرة، وقد تكون تللك الذكريات قد تركزت في لاوعي الفنان لمطاو عـة الزمن و إعـادة انتاجها بمواد 
مختلفة لمحاكاة بيئته التكوينيـة ووجود الانسـان السيكولوجي و المسادي من خـلال ذلك التداخل و التحساور، التي يتجانس فيها الرسم بالنحت جميعها مستوحاة لاشعوريا وتمـازج الحاضر بالماضـي، ومـا من أثرِ فنيّ إلاّ وهو

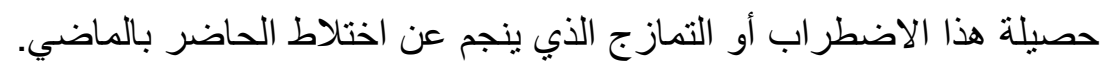
مؤشرات الاطار النظري:

ا. تأثر وتأثثر الرسم العر اقي المعاصر، في التجارب الاوربية، ويكون التأثر بدرجات متفاوتة، وبذلك فهو امـا يكون نسخا، او تقليدا، او اقتباسا، مستمدة مما تطرحه الساحة الاوربيـة من اتجاهـات واسـاليب مبتكرة، كان لله الاثر الكبير في احداث تحولات مهمة وشاملة في مجمل الا عمال الفنية العر اقية . r. الابتكار بالخامـة والمواد، وآليهـ تفعيلها وعدم الاستقرار والتغيير المستمر المبنـي على التجريب وايجـاد الخصوصية في النتاج و النوعية، فضلا عن احداث تغيير في ملامح المشهد التشكيلي العر اقي السائد، بمـا ينسجم وتظورات العصر ، ومفاهيم الفن التثكيلي العالمي المعاصر. r. . الاتجاهـات الحديثة المعاصرة عملت على تفكيك الثكل و عدم تماسكه من خـلال تقويض مبداء الوحدة و اعادة تركيب النص، التي أثرت بالفن العر اقي وامدتهم بمعطيات الابتكار ، والخلق، و التحول . ع. . ابتكار للتقنية واستخدام الخامات الجاهزة و المستعارة من المحيط وتوظيفها وتركيبها في السطح البصري ، مما احالها الى و لادة اثكال جديدة وتغير في وظيفتها ، و اعطاء دلالات فنية مستحدثة . ه. عـد مـن الفنـانين العـر اقيين اسـتفاد مـن مـوروث الحضــارة الفــي الواسـع والمتنـوع كمرجـع، واسـتلهام

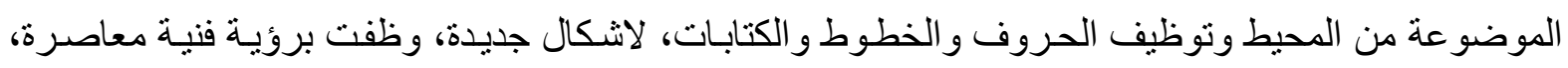

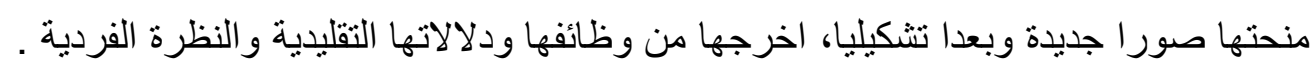

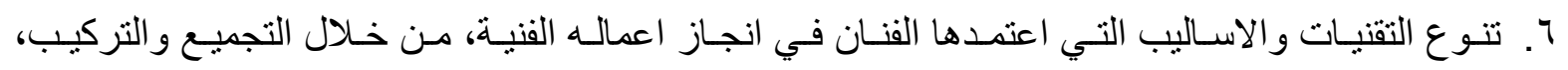
و استخدام النفايات و الاشياء المستهلكة بغية تفعيل قيمة النص في فنون مـا بعد الحداثة ـو السيادة الكلية للتقتيات اللونية وتقنية المادة .

V. . الخروج عن دائرة الرسم التقليديـة والقو اعد الثابتـة الممنهجـة في عمليـة الخلق الفني، وتوظيف التقنيات

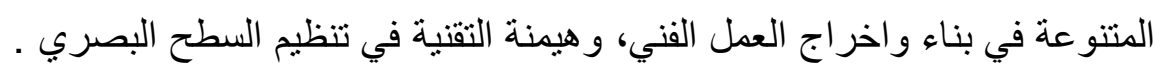

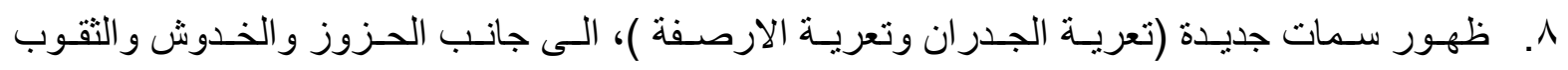
و الثخبطة والثقوق و الحرق، و هذا ادى بدوره الى تنوع في السمات و الخصائص الجمالية والفنية. 9 ـ. التجريب في مواد اخرى متعددة، وعدَّ المـادة وطر ائق توظيفها عنصـر ا اساسيا في الفن ،وتداخل اجناس واصناف الفن ضمن مبدأ التجنيس، و غياب جنسية العمل الفني . • 1 . التحول والانتقال والتحرر من الفردي التقليدي السائد، والاتجاه الى تعدد في الرؤى، من خـلال اختراق للطر ائق التقليدية في توظيف المواد والالوان المختلفة وتفعيلها في السطح البصري من خلال التلقائية في التفعيل 


\section{النفصل الثالث إجراءات البحثث}

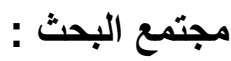

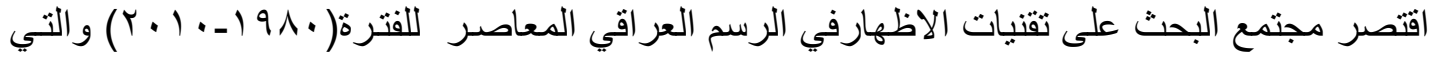
شملت اعمـال جيل الثمانينيون والتسعينيون ، واعتمد الباحث على المصسادر والانترنيت و الحصـة الاكبر من خلال روية ومتابعة الاعمال و الزيارة الميدانيـة للفنانيين والاسـاتذة المشـولين بتحليل العينات ومتابعة اعمالهم اثناء العمل ومقابلاتهم شخصيا، فضلاً عن الاطلاع على المصسادر و النشـرات المطبو عـة للتعرف على مجتمع و عينة البحث فيما يخص الحركة التتكيلية في العراق، وتغطية البحث. عينة البحث: قام الباحث حصر وتحديد العينات بعد تصنيف أولي اثتمل على المتغير الظـاهر في اسـاليب تقنيات الاظهار في التشكيل اخذا بنظر الاعتبار تمثيل العينات في ضوء اهميتها في معطيات التشكيل المعاصر، وبلغ عدد الاعمـال المحددة ( r ) اعمـال من جيل الثمانينييون ( r ) اعمال من جيل التسـعينييون ، وقدتم اختيار العينات قصدياً للمبررات الآتية :

1- اختيار الاعمال بما يلائم اتجاهات مابعد الحداثة ( المعاصرة ) وتمثيلها للمجتمع الاصلي. r- اختيار الاعمال التي استخدمت تقنيات وخامات مختلفة وحققت تحولات في السطح البصري،

$$
\text { على وفق المتغير في الاسلوب و التقنية . }
$$

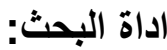

من أجل تحقيق هدف البحث المتمثل في الكثف عن ثقنيات الاظهار والمتغير التقني و آليه الاشتغال وتوظيفها لبنية السطح البصري في الرسم العر اقي المعاصر .اعتمد الباحث على التاسيس المعرفي للمتغير الاظهاري للتقنيات، فضلا عن المؤشرات التي اسفر عنها الاطـار النظري في بنـاء البحث ، واعتمـاد المنهج

$$
\text { الوصفي التحليلي. }
$$

المسح البصري والوصف العام: يتكون تكوينين اشكال خر افيها بدائية ذات منحى اسطوري يتكون من شكلين كل شكل يحمل متلثنين احدهم على شكل كائن طائر او حيوان بدائي والاخر اشبه مـايكون الى الحارس الثخصي و اقفا عند بو ابه لحر اسه كائن مقدس، تعامل مع اشكاله بلون اسود على ارضيه حمر اء متمـازج مـع الابيض ومتداخل مع اللون الوردي ذات بقع عفويه يشغل الخلفية التي توزعت غير منتظمـة بتكوينـات و اشكال عشو ائية. تجربة مزج فيها الفنان بين المرئي والمتخيل فجاءت اعماله تحمل مفردات بيئية واخرى اسطورية تخيلية تتسم بالغر ائبية و الفنطازية. فالعمل لا يمكن تجزئة عناصره كلها متر ابطة شكليا ولونيا، عمد فيها الفنان 
تحديد عناصر تثكيلية باللون الغامق، وقد شملت عناصر العمل وحدات ثراثية اخذت من هيكلة البسط الثـعبية واخرى زخرفية او صورية تجريدية ابتكارية.

و على الرغم من الاحساس بغياب التكوين المألوف فقد ملأ مركز التكوين الثيء الكبير بتلك الاشكال، وقد ثلمت حافة منه و التي أضافت جمالية للتكوين، ولثدة التكوينات المرسومةعلى مسـاحة اللون الاحمر وشدة الو انه السوداء الصريحه اضافه الى البقع البيضاء الذي كسر بها رنابه النسق، فقد كوّن علامـة مهيمنة و اضحة. الاشكال منغلقة على نفسها ولا تمت بأية مرجعيات طبيعيـة، فضـلا عن تحطيم تلك المر اكز باثكال وتكوينات عشو ائية غير منتظمة في المركز. لقد وزِت عناصر هذا العمل بشكل عشو ائي لا يحكمه نظام معين، كما ظهر في هذان الثكلان من العمل وبشكل افقي على هياة حيوان خر افي،فيما توزعت الالوان المقتصرة على اللون الابيض و الاحمـر و الوردي الفـاتح و العميق مكونـة فيما بينها هارمونيـة تو افقات لونيـة مـا عدا تضـاد الاببض و الاسـود. اللـون الابيض تـوزع على شـكل عشـوائي ذات بقع موز عـه على العهل بكامله حيث شـغلت ربـع الارضية الرئيسية في السطح المصمت .

بينما امتد الاحمر في مساحة كبيرة ومهيمنة كسرت انساق الاشكال والرتابـة. وتم توزيع الالوان لخلق

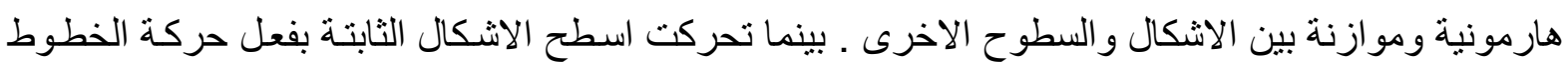
النزقة المتوثبة بمختلف الاتجاهات و التي اضـافت حركة وحيويـة جمالية خلخلت الاسطح الصلدة، كمـا ان هذه الاشكال طقوسية طلسمية ثبتت مع الخلفية كالجدار بعدّها رسـالة مرسلة. بينما اضـافت (التبقيعيـة) في المسـاحة المحيطة حولهاحركة وحيوية وتوازن، فعناصر اللوحة من الاشكال والبقع والالوان كونت علائق فيما بينها لصـالح العمل الفني الذي يجمع بين الرسم و الكر افيك، و عمومـاً الاشكال تنطوي على نزعـة سحرية جمالية لصالح الثكلانية بعيدة عن المضامين الانسانية والاجتماعية الذي كان الفنان مشغو لاً بها سـابقاً في السبعينات، بعودة وتلاحم استمد فيها اشكاله مـن الحضـارة وامتز اجها باشكال غرائبيـة واشكال هندسية وخطوط منقطـة و اشكال طائرة لخلق الايهام وتفعيل الخيال.

$$
\begin{aligned}
& \text { نموذج (r) } \\
& \text { اسم الفنان : هاثم حنون } \\
& \text { سنة الانجاز: } 1991 \\
& \text { ابعاد العمل : · كسم × · • سم }
\end{aligned}
$$

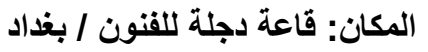

المسح البصـري والوصف العـام: للعمل الفنـي يشتخل ضـن الاتجـاه التجريدي يتو اشـج مسع معطيـات تشخيصية . يحتوي على ثلاث وحدات اساسية : الوحدة الاولى مكونة من مستطيل يعلوه مثلث في يسار المشهـ ـ و الوحدة الثانيـة: مسـاحة شبه مسـطيل بـاللون و عليـة الـوان بنفسجي و اصـفر واحمر واخضـرفاتح نوازيها وتساويها في في توزيع الثيمات في منتصف المشهد، ووحدة ثالثة على يمين المشهد شبه مستطيل سوداء اللون تتوزع على سطحها اثكال وخطوط مبعثرة ـ. هذه الوحدات الثتلاث تشـل ثلثي المسـاحة تقريباً بينمـا شـلت الارضية باللون الاوكر ثلث مساحة اللوحة. 
أما المستوى التركيبي للمساحات المسطحة ذات البعدين فالتكوين مفتوح نحو الاطر اف مستثمر اً لطبيعة العلاقات بين المستطيلات الثناث لتكوين شكلاً مربعاً اضـافة الى ان اللوحـة مربعـة اساسـاً وهذه أحد اسقاطات اللاوعي الجمعي، وأحد رموز الانسانية. وهو أحد المرجعيات الفكرية لرمزية الوجود كما في الالواح السومرية

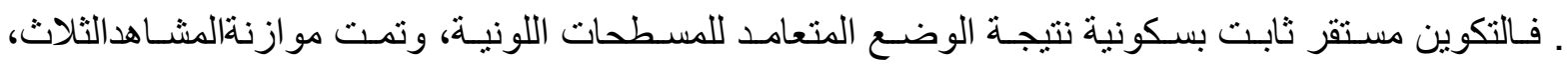
بتكوينـات صـغيرة ملونـة على شكل مربعات ودو ائر وخطوط صـغيرة اشبة باللغـة الصـورية وازنت وحدات

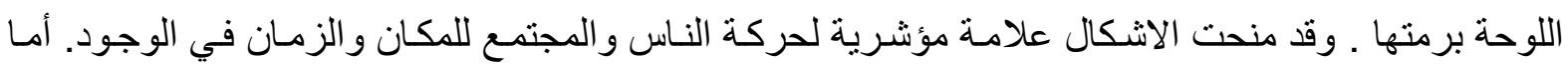
الخط فقد تر اجع لصالح المسطحات اللونية ولكنه يظهر بشكل صريح دلالالة على اعطاء رموزو علامية من خلال الخطوط الرفيعة الينة لمعالجـة الاشكال التشخيصية ومعالجـة ارضية اللوحهة و الاشكال المهيمنة بخطوط متشابكة بآلة حادة كر أس سكين الالوان او رأس مدبب . حيث انه استغل طر اوة الالوان قبل ان تجف ـ و اللوحة مرجعياتها غيرواقعيـة وثيماتها تعتبر ضمن اطسار التعبيريـة التجريديـة، فأن الفنان قد تجـاوز هذه الطروحات ليؤكد على الصياغات الفنية الجمالية في توزيع الخطوط و الالوان والمسـاحات وتعالقها وبنـاء دلالتها في ارجاء اللوحة، ممـا اعطى للعمل الفني قيم جماليـة تتيح لعين المتلقي أن تتنقل بحريـة مفتوحسة. ثم اضـافة الخربشـات للخطوط و النقاط و الالـوان الحسارة و البـاردة لاعطـاء محض حركة وقيمـة جماليـة تزيينيـة وللتقليل مـن رتابـة المسطحات الممتدة طولياً، كمـا ان توزيع الالوان في المستطيل الافقي العلوي واضـافة اشـرطة مـن الالوان المتداخلة في حافة الجانب الايسر من اللوحسة لموازنته واضـافة قيمـة جمالية بـاللون، أمـا الخلفيـة فهيمن عليها الاصفر الاوكر حيث اعطى شاعرية مع مجموعة الالوان الاخرى وشفافية لونية، ثم انهه عمد الى تداخل حواف

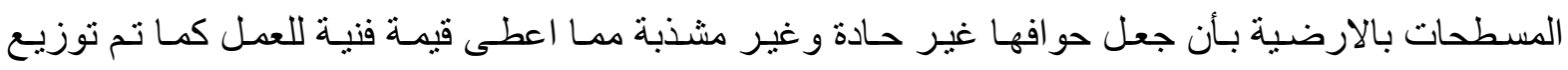

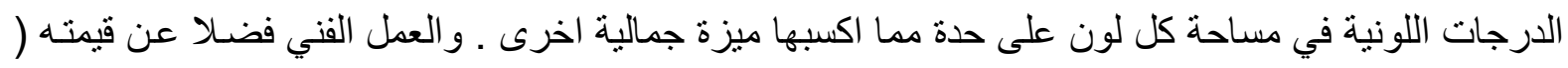
الجمالية) . فقد استمد رؤياه الفنية من التراث السومري و المحلي تحيط بها هـالات، و على الرغم من مرجعياته الر افدينية فالعمل الفني تغذيه عدة مصادر باستعار ات واضحة يمكن تقصيها في الاتجاهـات التعبيريـة التجريديـة مركية للرسم الامريكي الحديث عند الفنان ( مارك روثكو) في توزيع الالوان و المسطحات اللونية وشفافيتها ومعالجـة نهاية حو افها ،كما تذكرنا باعمال الرسام الامريكي التعبيري التجريدي الآخر ( هانز هوفمان) ولكن في اختلاف لهاف لهان قوة الالوان وحدة حواف الاشكال عند هوفمان وتنتاص عمل آخر لروثكو نلاحظ اقتر اب في التقنية و المسـاحات

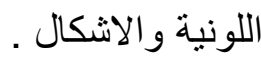

نموذج(ب).

اسم الفنان : كريم رسن

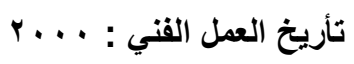

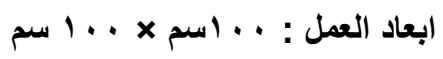

عمل تجريدي وحـروف، اشـبه بسطح او جدار قديم عتيق ، امتلـئ باثــار ات و علامـات وخربشـات وحروف وضـعت بتلقائيسة و عفويـة لاترمز الى دلالـة معينـة، اثـار ات وخطوط سـائله و مموهـة. و هنـاك نقطـة

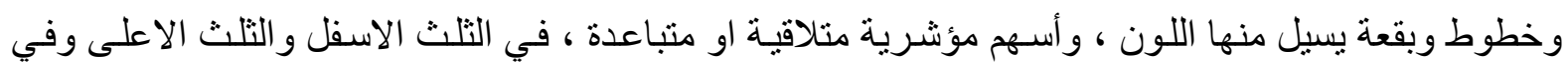
الوسط بؤرة مشوشة من اللون الاسود العاجي ، الحركة مضمرة توحي باتجاهها المائل من اليسـار الى اليمين 
من زاوية اللوحة اليمنى العليا الى زوايا اللوحة اليسرى السفلى، وكانهه جدار قديم فيه تثققات وتقوب وحزوز ورموز متباينة .وحدة الشكل اتخذت نصف اللوحة تتكون من تشققات ورسوم اشبه بالرسوم الجداريـة السومرية اضافه الـى لمحسه معاصـرة بحركة سوداء كسرت رتابه و هـاجس القلق المنبعث من تللك التكوينـات في التلث الاعلى الى يمين اللوحة ـ وفي الثلث الاسفل مدرّج مرتفع يثبه مدرجات زقورة سومرية وشبيه بكوخ ريفي.

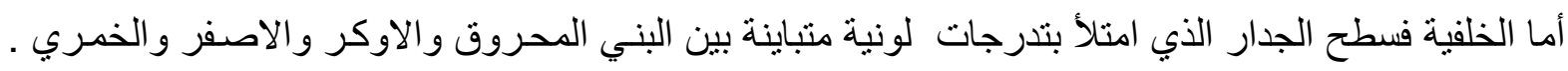

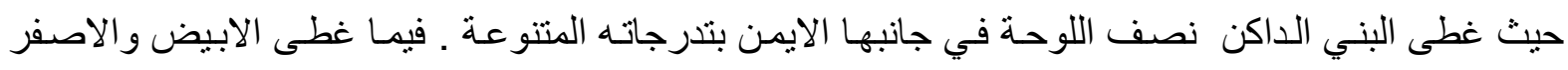

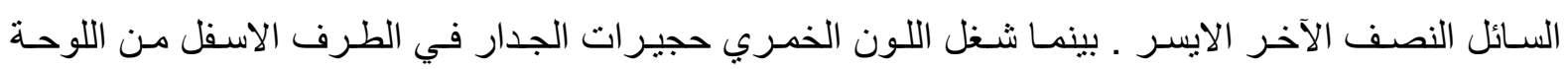
والاخضر الزيتوني فقد امتد مستقيماً افقياً في قاعدة العمل مكونـاً مركزاً دلالياً يقود العين الى مركز السيادة و التكوين في الوسط حيث التكوينين المتقابلين .

الحركة ووضع الاشكال و التشققات و الاشـار ات و المساحات اللونيـة موزعـة في الوسط و على الاطر اف

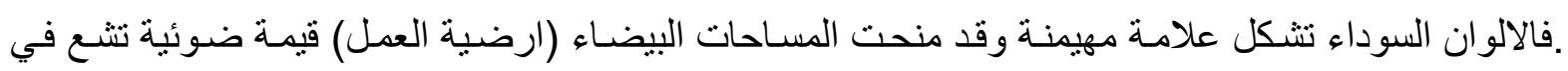
ارجاء فضاء اللوحة .

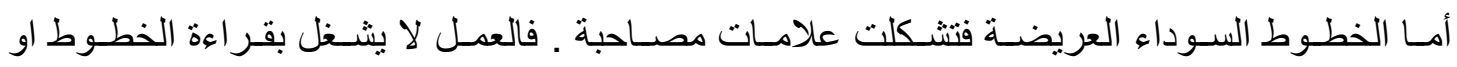
تحوير ها وفق قو اعد ومساقط الحروف عند الخطاطين . بل تحول الى اشكال متناغمـة. رغم انها تتنمي للواقع (للجدار) الذي يصدمنا بوجوده الفيزيقي لكنها تشتغل ضمن النظام التجريدي الحديث، و العمل يعتمد بنسبة

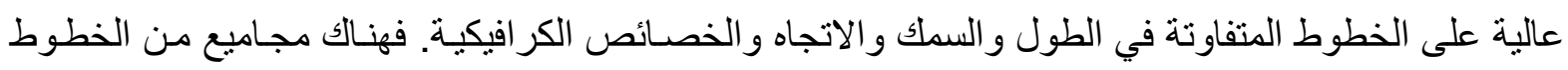
النسيجية الرفيعة في كل ارجاء العمل الفني وخربشات خطية سوداء وبيضاء تتعالق معها كما ان هناك مجموعة من الخطوط و العفويـةعلى يسـار اللوحسة تشكل (شـخبطة) وخطوط وظفت على عجينه الوتربروف ، سوداء عاجية غائمة تقع في الثلث الاعلى من اللوحة والجانب الايمن و الاسفل ـ وبقع واثكال طوطمي (بدائية) سوداء غليظة في طرفي العمل. فهناك خطوط و اضحة المعـالم واخرى غائبة الاطر اف أو مموهـة رخوة ممتدة طافيـة على سطح الجدار (اللوحة) كما ان هنالك خطوط تمويه ظل في الوسط وضعت بتلقائية .

ان الخطوات البنائية الاولى التي اتبعها كريم رسن في تكوين البنية الكلية لعمله تحققت عن طريق: تهيئة السطح التصويري ، بمعالجـات تقنيـة لمو اد عجينة التركيب، قام بتغطيتها في مر احل لاحقة بانزياحات

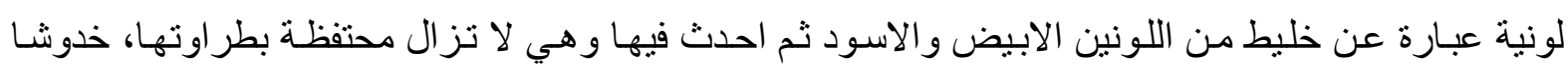
وحزوزا، جعلتها تقترب في سماتها من سمات السطح الجداري، غير انها افتقرت للثقوق و التفطرات التي لترني وظفها الفنان وضمنها في الكثير من اعماله الكر افيكية. ثم قام بطلاء الحافة السفلى من ذلك السطح، بلون داكن

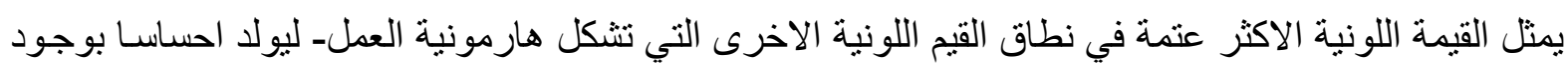

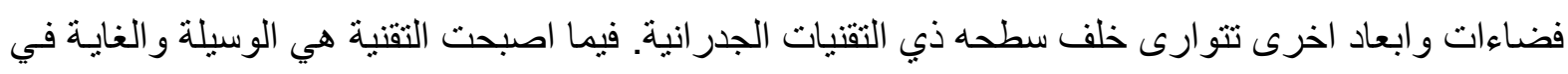
توجيه الاشكال نحو قيمة فنية ومضامين جمالية تحيلنا الى مناخات تراثية قديمة بدائية سومرية، ورموز انسانية كونية تذكرنا بطروحات شاكر حسن آل سعيد حسب مفهوم لوحة الجدار ـ وهذا ما نلاحظه في اعمال كريم رسن 
في المناخات اللونية والتقنيات حيث استخدم مواد خليطـة من الرمل و الغر اء والخشب (البورد). بالاضـافة الى تأثير ات تابيس و استخدام الخربشات و الرموز و العلامات و التي تذكرنا باعمال (بول كلي) و العمل في مرجعياته

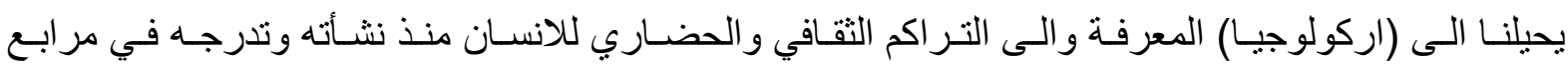
الحضارة وحتى انسـانتا المعاصر في ابجدياته ووثائقه وخر ائطه الاثريـة الو اقعة في قبضـة الزمن لا محالة . و على الرغم من ان كريم رسن ار اد ان يجعل عملهه هذا مغـاير المـا كـان ينتج من اعمـال في دائرة الرسم العر اقي، باتباعه اليات تنفيذ لم تاخذ ابعادها الواسعة بعد، في طريقة توزيع مادته الطلائية ذات العجينـة العالية، وتركيبها فوق سطح اللوحة (الملمح الجذاري) بكل ما ينطوي عليه من :شقوق، وحزوز، وتفطر ات، وتمويهات، فانه لم يكن قادر ا على الابتعاد كثير ا عن صفة المقاربة مع الكثير من الاعمال الفنية العالمية.ويجد الباحث انه لو اجريت محاولة لاز الة الخطوط العريضه و التمويهات الاخرى ذات اللون الاسود من اعلى السطح الذي تحوم فوقه، لاصبح اكثر مقاربـة من اعمـال: البرتو بوري في فتحسات اجسـاد شخوصـه التي يتوزعها الرصـاص، وتقنيات روبرت روشنبرغ في الانزياحات اللونية التي تسيل فوق طبقات اخرى من اللون التي تقع تحتهافي تقنيته المشهودة. فضـلا عن إن هنـالك استغر اق واسترخاء وتامل مضمونه الكوني مـع قر ائنسه (علامـة رمزيـة) للفناء و عبث الوجود، فلم يبق للوجود غير الاثر.

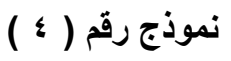
اسم الفنان : جبار عبد الرضا

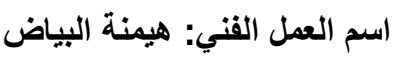

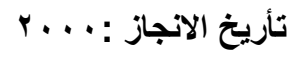

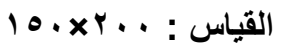

اتسم العمل بمجموعة من التقسيمات ذات الاتجـاه المتعارض بثناث وحدات مستطيلة الثكل متجـاورة تحمل في طياتها هيئات و اشكال مهيمنة ،مع غلبـة وهيمنة جزء على جزء اخر هيمنـة حجمية او لونيـة فهو يستقطع تكوينات العمل ليفّعل سطحه البصري بمجموعة من المرموزات الثكلية التي تمثل قطع ودمسى ومو اد متروكة مركبة وبقايا اشياء و اسلاك ومعالجتها بشكل مختزل مع تأكيد قيمة الخط و المحافظة على حيادة اللون، فهو يترك بعض الاجز اء لتبدو وكانها مرسومة بطريقة التخطبط الذي يتناسب مع طريقة تنفيذ هذه الاشكال على ملى ارضية من اللون الابيض. ان تللك الاشكال ذات الطبيعة التركيبية شغل بها الفضاء في الاعلى من الجهة اليمنى الوسطية بتلك الاشكال داخل التكوين الحاضن بثيمة متحركة، كاسر الرتابـة الوحدات و اعطاء دلالات متعددة بمساحة رباعية مائلة من اللون البني التي جاءت باللون الابيض و على هيئة اشكال مركبة نافذة، حددها الفنان

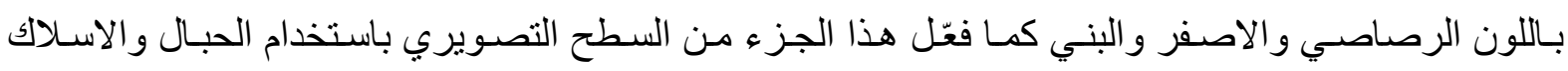
ولصقها على اجز اء منه مع ترك مساحات وفضاءات تتحرك فيها الاشكال بحرية ومرونة. اما المساحة المتبقيـة من فضاء اللوحة الذي ينبني على قاعدة بـاللون الاوكر الفاتح فقد فعله باتشغال الجزء السفلي في يسـار العمل وفوق الثريط الذي يمتد على كامل الجزء السفلي بحزوز وحدود مؤسس بـاللون البني وفعّله بتحريك لبعض الاشكال و المرموز ات الثكلية ، وبذلك يخلق الفنان نو عا من التماسات التفعيلية ليس بدلالة الثكل. و اللون وانمـا

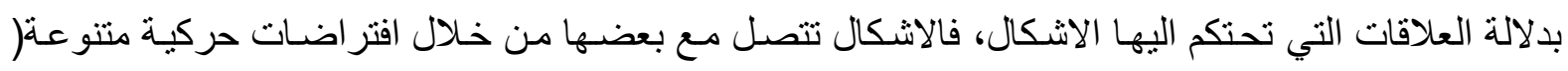


لاتثبت ) والاشكال المركبة تتحرك بطريقة افقيـة وعموديـة منو اصلة مـع اشكال مبعثرة في مسـاحة فضـاء

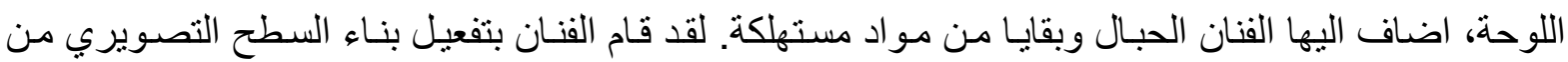
خـلال اللـون الذي يتنـاوب بالحضـور مـع اختلاف البنيـات الثـكلية (رصاصـي، ورصاصسي مـزرق، والبنـي و الابيض والاوكر الذي مثل فيه الاشكال)، وقد عمد الفنان حشد وتوظيف مجموعة من الاشكال المعالجة بشكل مختزل وبسيط وبخطوط دقيقة في المسـاحات الهندسية المحددة الاشكال؛ لتحقيق التفاعل البنـائي لمجموع العناصر المكونـة للمشهد البصري، ان هذه الاشكال مختلفة في دلالاتها وسماتها الثكلية ولكن هذا التواصل البنائي يتفعل من خلال حر اك هذه البنى الثكلية في وسائطها الناقلة وطبيعة سلوكها الجمالي.

\section{نتائح البهحـ:}

بعد الانتهـاء مـن الاطــار النظري، واستنادا السى مـا اسـفر مـن تحليـل عينـة البحث، فقد التقى جيـل الثمانينيون بجيل التسعينيون بالكثير من الاعمـال في الجوانب الثكلية والتقنية و البنائية وقد تمثلت اهم جوانب الالتقاء و المقاربة، وقد توصل الباحث الى النتائج الاتية: 1- الاشتر اك في بعض التقنيات المكتسبة والمبتكرة الذي حصل في كلا الجيلين من بناء العمل الفني في جانب الالصاق و انزياح الالوان، وطرق اخرى بتقنيات متعددة و التبسيط والاختز ال. r- استخدام نفس المو اد والخامات و العجائن الا ان جيل الثمانينيون فرصهم اكبر للدخول المواد و الخامـات

$$
\text { والاطلاع الاوسع بعد حرب r... . . . . }
$$

r- ابر از التفرد و الخصوصية السمة المشتركة وكذلك الاخذ من الماضي و الموروث وتطوير السـابق وهذا نر اه في جيل الثمانينيون واما التسعينييون اعتمد بالثكل الاكبر على المهارة والتقنية ومواكبة الاتجاهات الحديثة ع- - الاعتمـاد على الثيمـة البنائيسة المحليـة و التشـابه في توزيع الثيمـات الثـكلية في بعض الاعمـال وفي البعض الاخر الاستعارة عند جيل التسعين و الثمانين . هـ حصلت تتاصـات كثيرة ببين اسـاليب جيل الثــانينييون وجيل التسـعينييون وبين اتجاهـات التعبيريين التجريديين انفسهم. 7- - الالتقاء في المرجعيات الفنية التي استقى منها الجيلين سبل تطور هما فقد حاكى كل منهما مـا جاءت بـه المدارس الفنية الاوربيـة السـابقة لهمـا كالوحوشية و الرمزيـة و التعبيريـة و التكعيبيـة و التجريديـة والسريالية وفيما بعد المدرسة التعبيرية التجريدية بتقنيات و اساليب تختلف كل منهمـا عن الاخرى. ومع تتوع واستعارة الرو افد التراثية في التاريخ الفني للحضارة العر اقية فقد كانت رو افد التراث و الموروث الفني التي ينهل منها الفنانون اكثر غنى وتنوع، وقد عملوا جاهدين على استثمار وتوظيف الكثير من الاشكال والرموز والرؤى الفكريـة للحضارة بنبرة حداثوية معاصرة . V- التعبير عن الموضـوعات الغيبيـة و السـحرية والاسـاطير القديمـة والرمـوز المرتبطـة بالخيـال والكلمـة وتوظيفها بالصورة و الثكل على السطح البصري . 


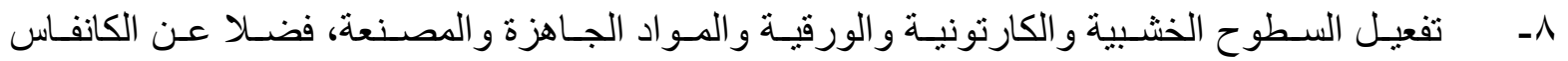
و السطوح الاخرى للرسم عليها، ومعاملتها بمعالجات تقنية حديثةو استمر ارا في تحديد تشـابهات وتقابلات اخرى في الرسم الحديث و الاتجاهات المعاصرة وتفعيل حتى النفايات و الخردوات المتروكة وتفعيلها في العمل الفني .

\section{|لاسبت:نتاجـات :}

اجمالاً من خلال تحليل العينات وما قدمه الاطار النظري بما فيه من فصول ،تبينت الاستتناجات عموماً الآتي : 1 - اثرت التقنية في الرسم العر اقي المعاصر من خـلال تحطيم الثكل وتفكيكه او تشويهه لغرض تصعيد در اما التعبيرو التفعيل ، وخلخلة النسب و الابعاد وتحوير الثكل وتجريديه جزئياً من علاقاته ليصبح مكتفياً بذاتـه بدون تفاصيل ، وتغيير في ابعاده وفق مبدأ تجريد الثكل الجزئي و استخلاص المكنون ـ و تجاور حيثيات الواقع

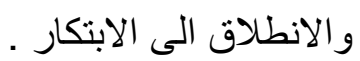

r- - لم يكن جيل الثمانينييون و التسعينييون مستقل تمامـا بذاته، بل هو نتاج لتحو لات متتالية حصلت في الفن التشكيلي بصورة عامة وفي فن الرسم بصورة خاصة. وهذا يعني انها استمدت الكثير من سمات اسلاليبها المتتوعة من المدارس الفنية السابقة لها، والتي مثلت كل منها في تطور الوعي الفني وتغيير اسـاليب و اشكال الفن واستحداث مفـاهيم معاصرة للجمـال والتقويم الجمالي، تسـاوقا مـع التطور ات الحاصلة في الفن الاوربي المعاصر . r- التأثر بفنون المدارس الاوربية الحديثة في تحو لاتها التقنية و الفكرية و الخروج عن المألوف في استخدام

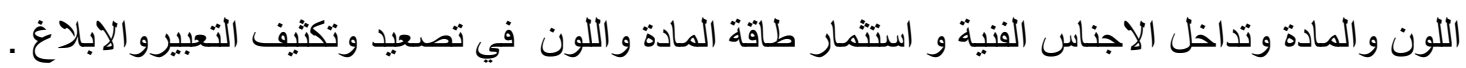
عـ - التأثر بتقنيات الاوربيين في الخشونة والمرونـة وتقنيات أخرى و اعتمـاد الكثافة والدسامة اللونيـة في ضربات الفرشاة السريعة المتوثبة المستخدمة بجر أة وبلا تهذيب و التأثر فيما بعد بتقنيات التعبيريـة التجريديـة في تجريب خامات ومواد صناعية في الخلطات وفي تحضير اللوحة أو اضافتها مع اللون او استخدام مواد معماريـة كالجص و السمنت و الغر اءو والرمل وذللك لملائمتها لحساتات التعبيرو المعاصرة ، و استخدام تقنيات الحفر و الحز مون

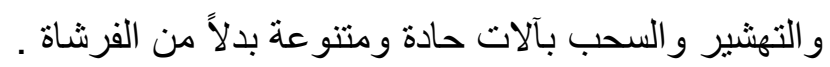
0ـ تر اكم الخبرة في الاطلاع و التجريب التي احتكم عليها الفنانون العراقيون والتنوع في الاسـاليب الذي ظهرت به نتاجـاتهم في الرسم، جعل من اعمـالهم التجريديـة مميزة عن الحقب السـابقة ،و استخدام تقنية المـادة الخالية من أي تمثيل و اقعي المرتكزة على مباديء التلقائية و الحركية والصدفة في الحصول على منجز فني بعيد عن أي ارتباط باليات وتقاليد ومفاهيم مما ادى الى ظهور اشكال جديدة في فن الرسم . 7- تغليب الجانب التقني على الجانبين الموضوعي و الثكلي، وتنوع طر ائق اظهاره و عده مظهر اساسيا في التعبير عن جماليـات الرسم العر اقي المعاصـر، ووسيلة مـن وسـائل الاثراء الجمـالي، المتحقق بعيدا عن ؤن متطلبات الشكل و الموضوع، وابتكار اشكال جديدة في الفن قد تبدو غر ائبية حينا و عبثية في حين اخر. 


\section{فائمة اشـكال العينة}

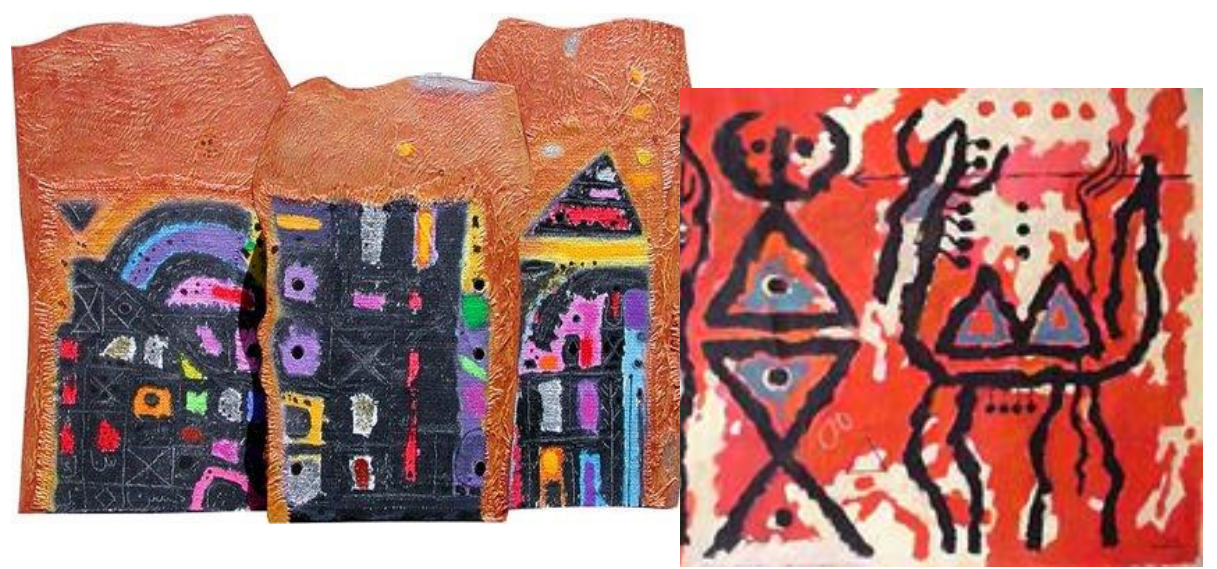

نموذج (r)

(1)

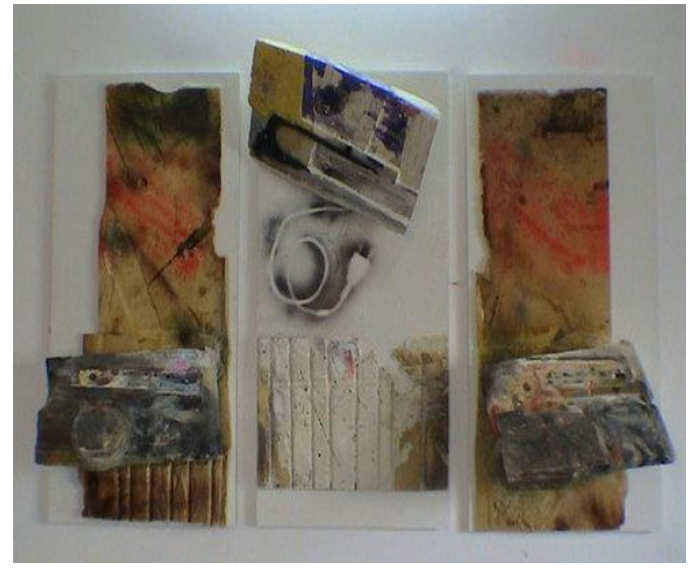

نموذج (乏)

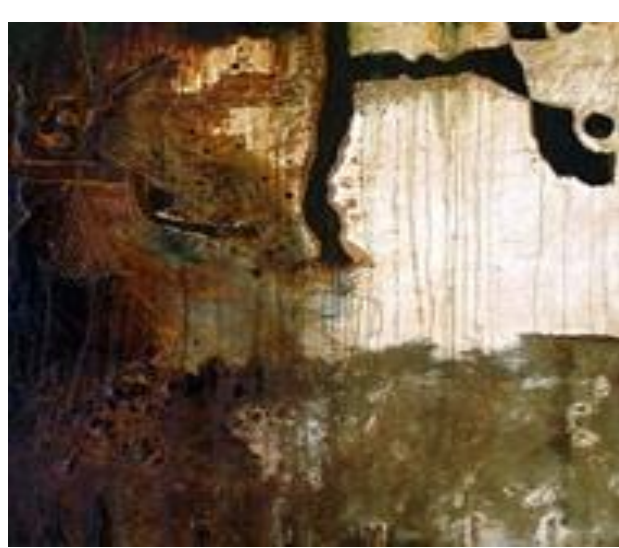

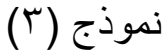

هوامش ومصسادر البـحث:

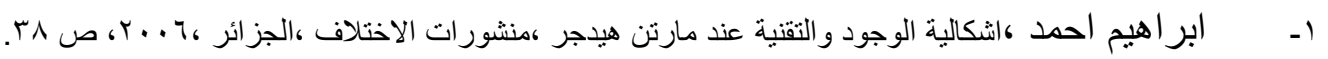

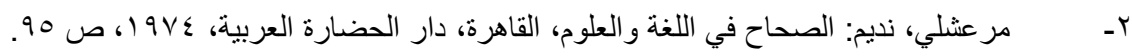

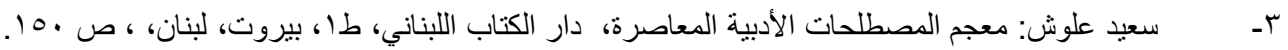

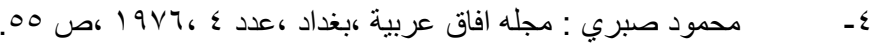

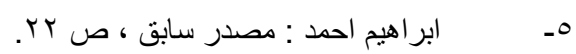

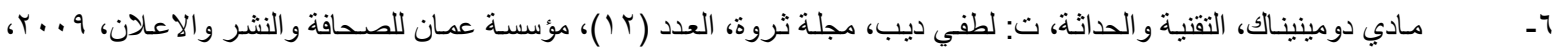

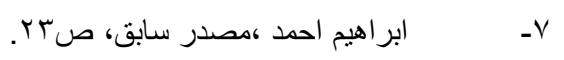

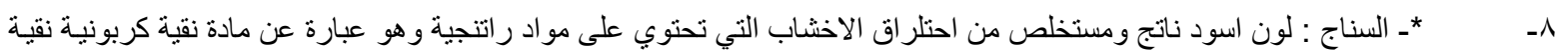

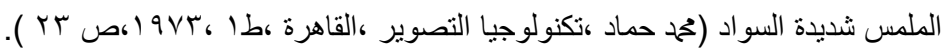

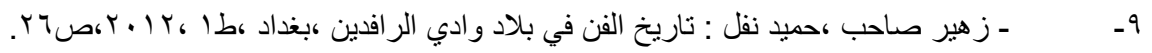

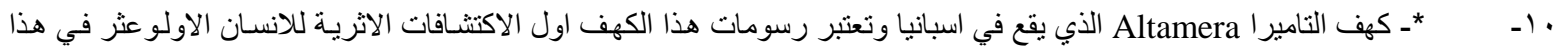

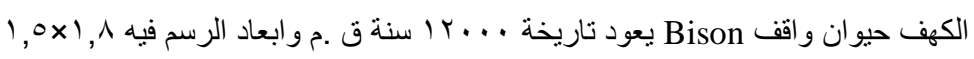




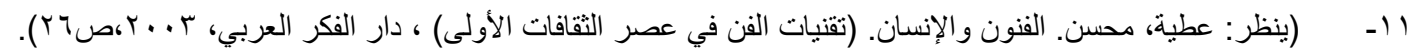

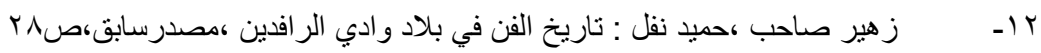

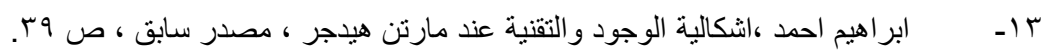

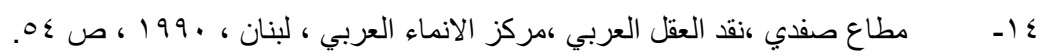

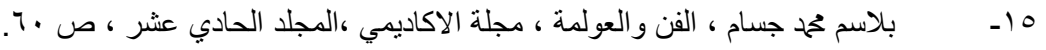

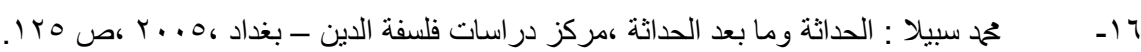

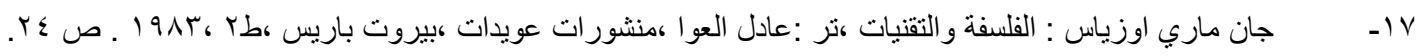

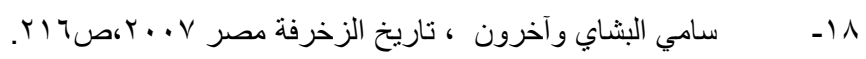

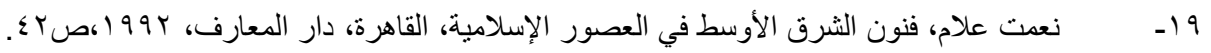

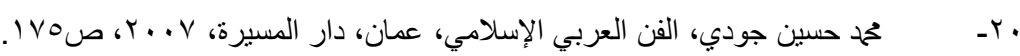

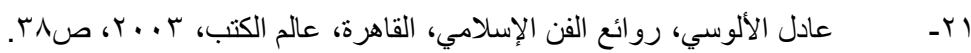

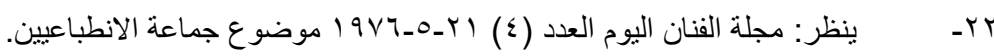

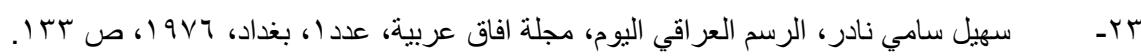

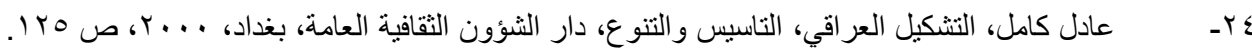

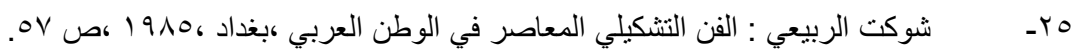

צr- ش شاكر حسن ال سعيد : الفن يستلهم الحرف (http://leilakubba.wordpress.com).

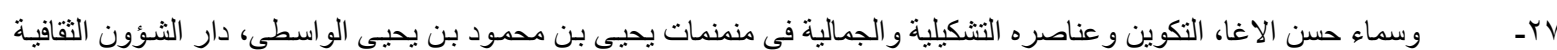

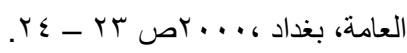

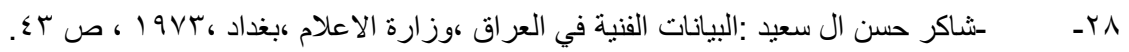

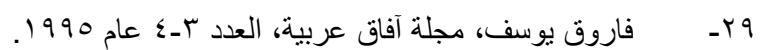

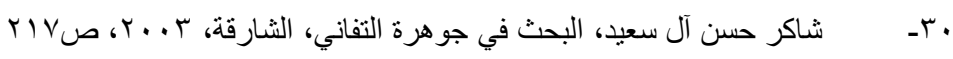

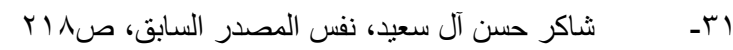

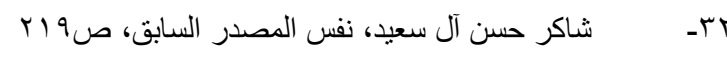

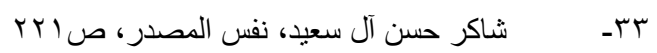

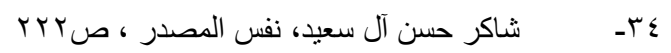

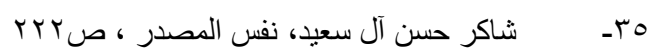

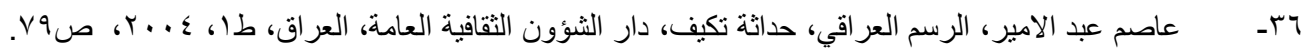

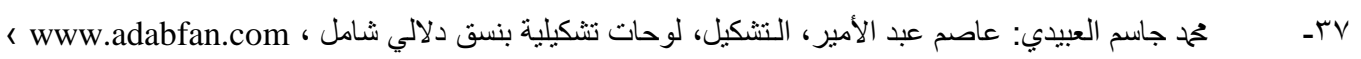

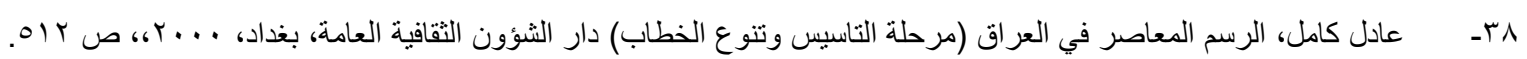

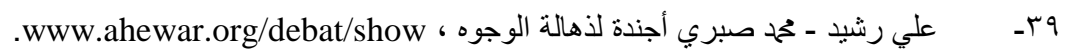

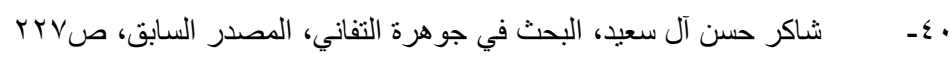

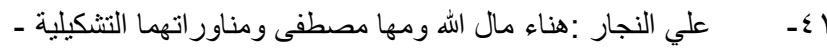

